\title{
THE PROTEROZOIC GRANITOIDS OF FINLAND: GRANITE TYPES, METALLOGENY AND RELATION TO CRUSTAL EVOLUTION
}

\author{
PEKKA A. NURMI and ILMARI HAAPALA
}

NURMI, PEKKA A. and HAAPALA, ILMARI, 1986: The Proterozoic granitoids of Finland: Granite types, metallogeny and relation to crustal evolution. Bull. Geol. Soc. Finland 58, Part 1, 203-233.

The granitoids are divided into four main groups: synkinematic (1860-1930 Ma, most commonly 1870 - $1890 \mathrm{Ma})$, late-kinematic (1800-1850 Ma) and postkinematic (ca. $1800 \mathrm{Ma}$ ) Svecokarelian granitoids, and anorogenic rapakivi granites (1540-1700 Ma). The synkinematic granitoids are the predominant component of the Proterozoic crust in Finland. They occur as composite granodiorite and tonalite plutons in schist belts, and form the large granitoid complex of central Finland, in which granites are common. The granitoids show I-type characteristics, Andinotype plate tectonics being the most viable mechanism to account for their genesis. Newly mantle-derived material was the predominat source of the granitoids, following fractional crystallization or more probably recycling within the crust. Subeconomic, porphyry-type $\mathrm{Mo}, \mathrm{Cu}, \mathrm{Mo}-\mathrm{Cu}, \mathrm{Cu}-\mathrm{Au}$ and $\mathrm{Cu}-\mathrm{W}$ occurrences are associated with late phases of the synkinematic granitoids. Minor higher temperature, vein-like mineralization containing $\mathrm{Cu}, \mathrm{As}, \mathrm{Mo}, \mathrm{Zn}, \mathrm{Pb}, \mathrm{W}$ and $\mathrm{Sn}$ is related to the complex of central Finland.

The late-kinematic granites comprise diapiric intrusions and migmatizing granites mainly in high-grade metamorphosed schist belts. These S-type granites were formed after partial melting of Svecokarelian metasediments when metamorphism was at its peak in the thickened crust. Some rare-element pegmatites are associated with the granites.

The post-kinematic granitoids consist of small roundish composite stocks in southern Finland, and of multiple granite intrusions up to batholithic size, which were emplaced in the Presvecokarelian crust, in northern Finland. The geochemical and isotope characteristics of the former suggest mantle source, whereas the latter derived from the Archean crust. The late aplite granite phases of the granites in northern Finland contain local Mo mineralization.

Rapakivi granites, which exhibit A-type characteristics, occur as large multiple batholiths and stocks in southern Finland. Some of them are associated with gabbros, anorthosites and olivine-tholeiite diabases. The anorogenic rocks are indicative of the beginning of intracontinental rifting of the uplifted Svecokarelian crust. The basaltic mantle magmas evidently initiated major remelting in the granulitic lower crust, giving rise to rapakivi granite magmas. The late topaz-bearing phases of the rapakivi granites, with their marked geochemical specialization and characteristic petrographic features, contain greisen-type $\mathrm{Sn}-\mathrm{Be}-\mathrm{W}$ and $\mathrm{Zn}-\mathrm{Cu}-\mathrm{Pb}$ sulphide mineralization.

Key words: granites, rapakivi, geochemistry, ores genesis, Proterozoic, Finland.

Pekka A. Nurmi* and Ilmari Haapala: Department of Geology, University of Helsinki, P.O. Box 115, SF-00171 Helsinki, Finland.

* (Present address: Geological Survey of Finland, SF-02150 Espoo) 


\section{Introduction}

Relatively few studies have been published in recent years on the Proterozoic granitoids of Finland, with the exception of the rapakivi granites (e.g., Vorma 1971, 1972, 1975, 1976; Haapala 1977 a; Vaasjoki 1977). Geochemical and isotopic studies are still fragmentary, and the granitoids have been classified mainly on a structural and petrographic basis.

The known ore deposits related to granitoids, which form the bulk of the Proterozoic bedrock in Finland, are of only minor importance, and relatively little explorational activity has been aimed at these rocks. However, associated with the granitoids are a number of small or low-grade mineral deposits and showings that exhibit various genetic types. Recent studies have shown that the late phases of the rapakivi granite batholiths are potential tin granites (Haapala, 1977 b), and that porphyry-type occurrences containing Mo, $\mathrm{Cu}, \mathrm{Au}$ and $\mathrm{W}$ are associated with certain Svecokarelian granitoids (Gaál and Isohanni 1979; Nurmi et al. 1984). Moreover, rare-element pegmatites are known to exist in many localities in southern Finland (e.g., Volborth 1954; Aurola 1963; Haapala 1966; Lahti 1981).

The present paper has two aims. First, to examine the character of the granitoids, principally in the light of existing geological, geochemical and isotopic data, augmented by recent chemical analyses. Special emphasis is laid on comparison with I-, S-, M- and A-type granites, which had earlier been reported mainly from Phanerozoic bedrock (Chappell and White 1974; Loiselle and Wones 1979; White 1979). Petrogenetic aspects of the granitoids and their role in the evolution of the Proterozoic crust are discussed. The second aim is to summarize the metallogenic features of the granitoids.

\section{Classification of the granitoids}

The bedrock of Finland comprises two major geotectonic units: the Archean basement in the northeast and the Proterozoic Svecokarelian complex in the southwest (Fig. 1). The boundary between these units in northern Finland is still a matter of controversy; evidently, large parts of the "Svecokarelian» schist belt are in fact Presvecokarelian (e.g., Gaál et al. 1978). Granitoids predominate in both the Svecokarelian and the Archean complexes. The supracrustal rocks in the Svecokarelian complex comprise a variety of sedimentary and mafic to felsic volcanic rocks that underwent low- to high-grade metamorphism and polyphase deformation (Simonen 1980; Gaál 1982 a).

The Proterozoic granitoids consist of Svecokarelian granitoids and anorogenic (post-orogenic) rapakivi granites. The Svecokarelian granitoids have traditionally been classified on the basis of their relationship to orogenic movements as synkinematic (synorogenic, primorogenic) and latekinematic (late-orogenic, serorogenic) granitoids (e.g., Eskola 1932; Saksela 1936; Wahl 1936; Eskola 1960). Sederholm (1932) reported a group of discordant small granitoid stocks in southern Finland, which are generally designated postkinematic. Simonen (1960) expanded the magmatectonic classification with petrographic and geochemical data and introduced several subgroups of synkinematic granitoids.

The radiometric zircon $\mathrm{U}-\mathrm{Pb}$ ages of the Proterozoic granitoids in Finland are presented in Fig. 2. The synkinematic granitoids show ages ranging from 1860 to over $1900 \mathrm{Ma}$, with a peak value at $1870-1890 \mathrm{Ma}$. They are roughly coeval with the Svecokarelian metavolcanic and mafic plutonic rocks (Aho 1979; Simonen 1980; Neuvonen et al. 1981). The few ages reported from the late-kinematic granitoids range from 1800 to $1850 \mathrm{Ma}$ (e.g., Vaasjoki 1981, p. 19; Hopgood et al. 1983; Korsman et al. 1984). The post-kinematic granitoids are grouped around 1800 Ma (Nykänen 1968; Vaasjoki 1977; Korsman et al. 1984). In northern Finland, the granites of the Nattanen type (Mikkola, 1941) and the Vainospää granite batholith fall into the post-kinematic age group (Patchett et al. 1981). 


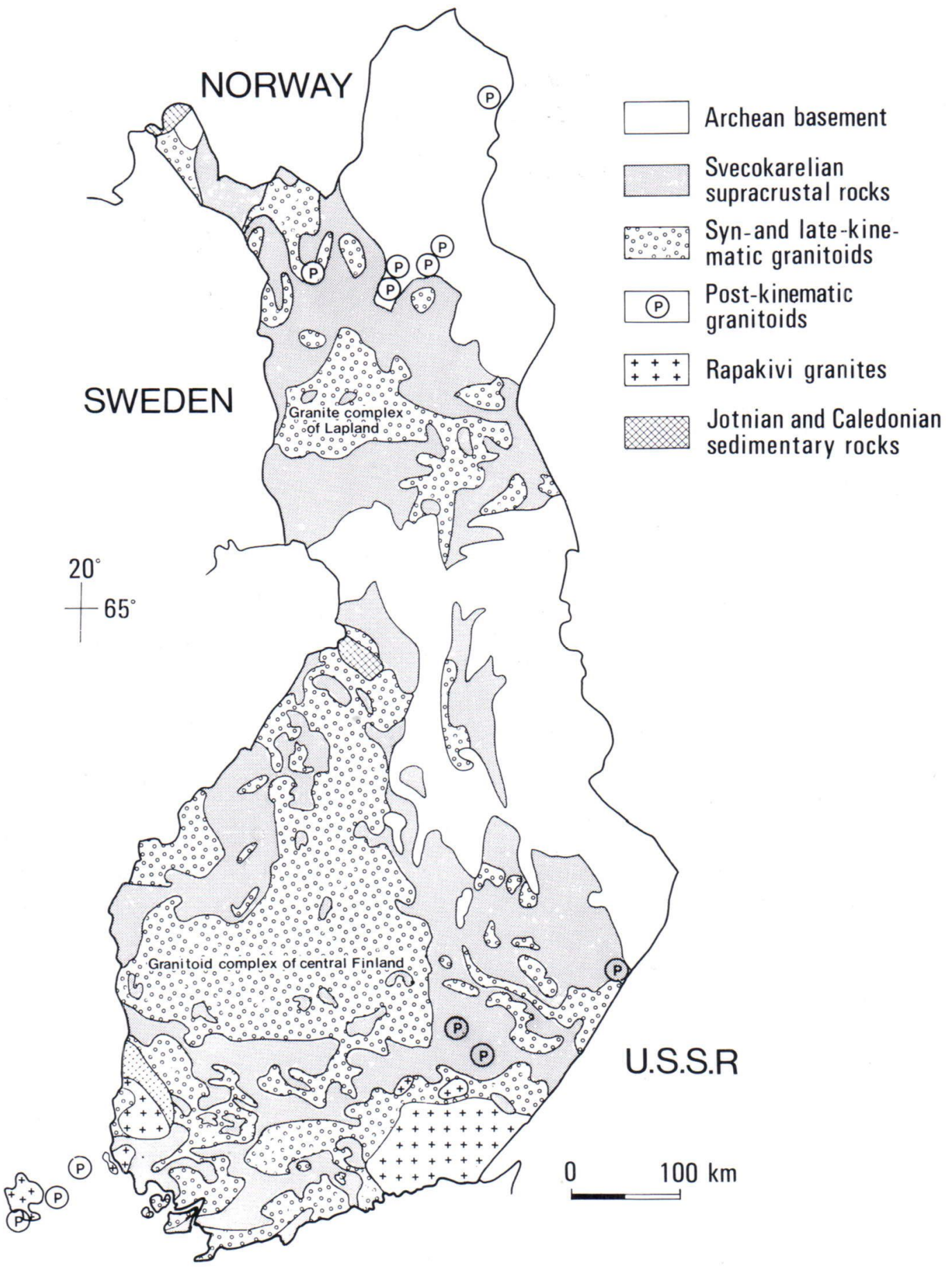

Fig. 1. Main bedrock units in Finland (simplified from Simonen 1980). 
The rapakivi granite batholiths and associated mafic plutonic rocks (gabbros, anorthosites and diabases) intruded after the Svecokarelian orogeny $1540-1700 \mathrm{Ma}$ ago, with each pluton having a characteristic age and a considerable time span between the early and late phases (Vaasjoki 1977).

\section{Synkinematic granitoids}

\section{Geological and geochemical characteristics}

Synkinematic granitoids predominate in the Svecokarelian region. They occur in schist belts as intrusions of varying size and form the granitoid complex of central Finland, which occupies an area of more than $35,000 \mathrm{~km}^{2}$ (Fig. 1). Typically, the plutons in the schist belts are roundish or elongated with a comformable mode of occurrence although cross-cutting contacts are not rare. The contacts with supracrustal rocks are usually sharp, and in places the granitoids form intrusive breccias. The texture of the granitoids varies from gneissic to non-foliated, depending on the time of emplacement in relation to regional deformation. Diapiric emplacement of the plutons is closely related to major regional compression (Nironen 1985). Many of the plutons have a non-foliated texture at their centres and a foliation parallel to the contacts at their margins (e.g., Värmälä stock, Härme and Seitsaari 1950; Käkövesi batholith, Nurmi et al. 1984 Hämeenkyrö batholith, Gaál et al. 1981). This may be a consequence of the deformation related to the emplacement. Younger regional deformations are visible as linear cross-cutting foliated or shear zones. Some of the tonalitic plutons, with ages slightly over $1900 \mathrm{Ma}$, are strongly deformed (e.g., Korsman et al. 1984).

Contact metamorphic phenomena have not been studied in detail, but they seem to be weak or absent. The metamorphic grade of the surrounding supracrustal rocks varies from low to high (Nurmi et al. 1984) but the metamorphism is not generally reflected in the granitoids. The

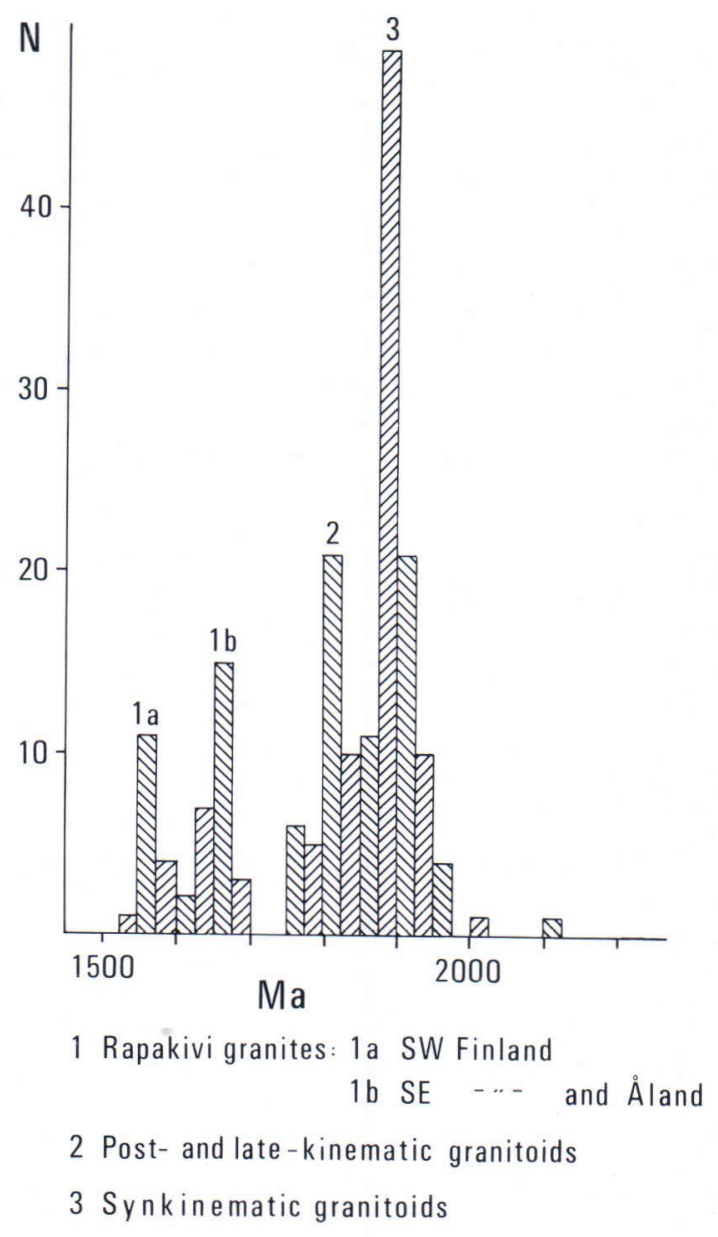

Fig. 2. Frequency histogram of the U-Pb zircon ages of the Proterozoic granitoids in Finland. (Compiled by O. Kouvo, pers. comm. 1979).

local alterations are related to autometasomatic processes.

The prevailing rock types are granodiorite, tonalite and trondhjemite. Charnockitic granitoids occur in some areas (Parras 1958; Wahl 1963). A composite structure is typical of many large plutons, the margins being composed of gabbro, diorite and tonalite, and the centres of granodiorite, trondhjemite and minor granite (e.g., Rautio batholith, Nurmi 1983; Käkövesi batholith, Nurmi et al. 1984). Multiple emplacement of magmas is often evidenced by intrusive 


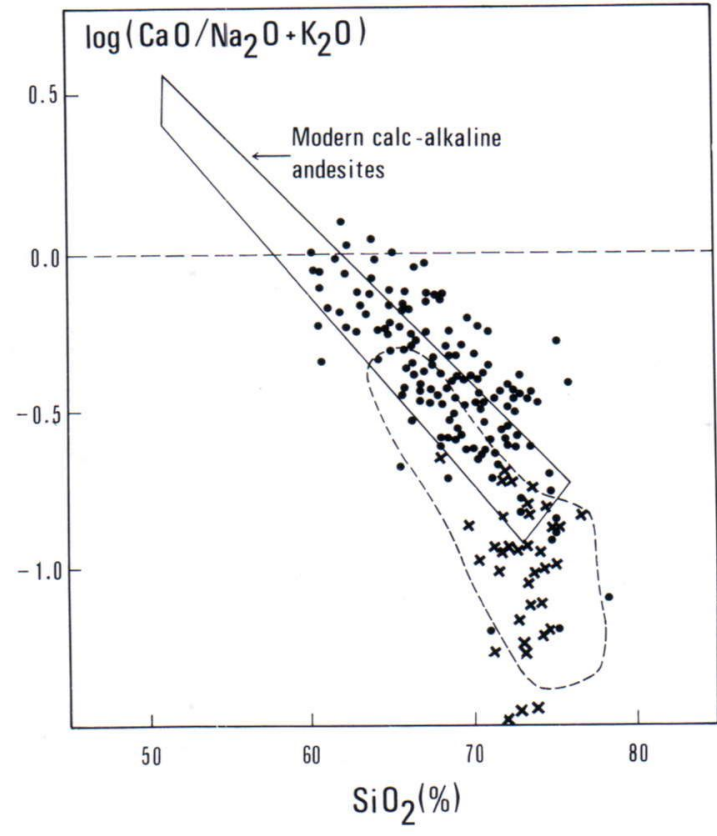

Fig. 3. Calc-alkali ratio - silica diagram of the Proterozoic granitoids in Finland. Dots refer to Svecokarelian synkinematic granitoids (143 analyses) crosses to late-kinematic granites (37 analyses), and dashed line to rapakivi granites (85 analyses). Data sources: synkinematic granitoids; older data referenced in Simonen (1960), others from Marttila (1976), Nurmi (1984) and the explanatory texts accompanying the 1: 100000 geological maps of Finland (published by the Geological Survey of Finland); late-kinematic granites, older data referenced in Simonen (1960), others from Härme (1965), Korsman (1977), the explanatory texts of the geological maps and unpublished data concerning the Renkajärvi granite (6 analyses); rapakivi granites, Vorma (1971, 1976), Haapala (1977 a) and Bergman (1981). Field of modern calc-alkaline andesites from Brown (1982).

breccias, sharp contacts or dykes, not only between different rock types but also within the prevailing granitoid phases. Plagioclase (oligoclase to andesine), K-feldspar (usually microcline), quartz, biotite and hornblende are present in varying amounts as major minerals. Typical accessory minerals are sphene, apatite, zircon and magnetite (Nurmi et al. 1984, Table 2).

The large granitoid complex of central Finland is made up of intrusions of different size, ranging in composition from gabbro to granite, the latter being common. The granitoids often exhibit
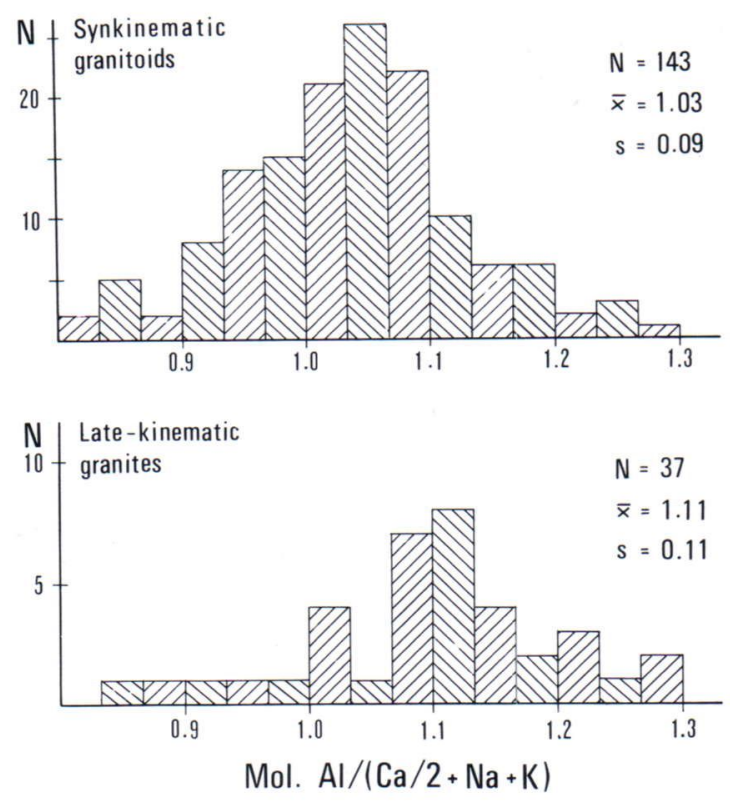

Fig. 4. Frequencey histogram of mol. $\mathrm{Al} /(\mathrm{Ca} / 2+\mathrm{Na}+\mathrm{K})$ ratios of the Svecokarelian synkinematic and late-kinematic granitoids in Finland. Data sources as in Fig. 3. $\mathrm{N}=$ number of samples, $\overline{\mathrm{x}}=$ mean, and $\mathrm{s}=$ standard deviation.

a coarse porphyritic texture and traces of polyphase deformation.

The level of emplacement of the synkinematic granitoids varies. Shallow-level intrusions are represented by porphyry stocks with breccia structures. Although not universally true, the complex of central Finland may exhibit a deeperseated level of emplacement than do the plutons in schist belts. This is indicated by features such as the rarity of supracrustal rocks, the coarse grain size of the granitoids, the occurrence of charnockitic rocks and the high-temperature mineralization.

The available chemical analyses of the synkinematic granitoids are plotted on a calc-alkali ratio - silica diagram in Fig. 3. The granitoids show a large variation in composition. Detailed studies have shown that prevailing intrusive phases are also geochemically zoned from more mafic margins to more evolved centres in some batholiths (e.g., Gaál et al. 1981; Nurmi and Iso- 

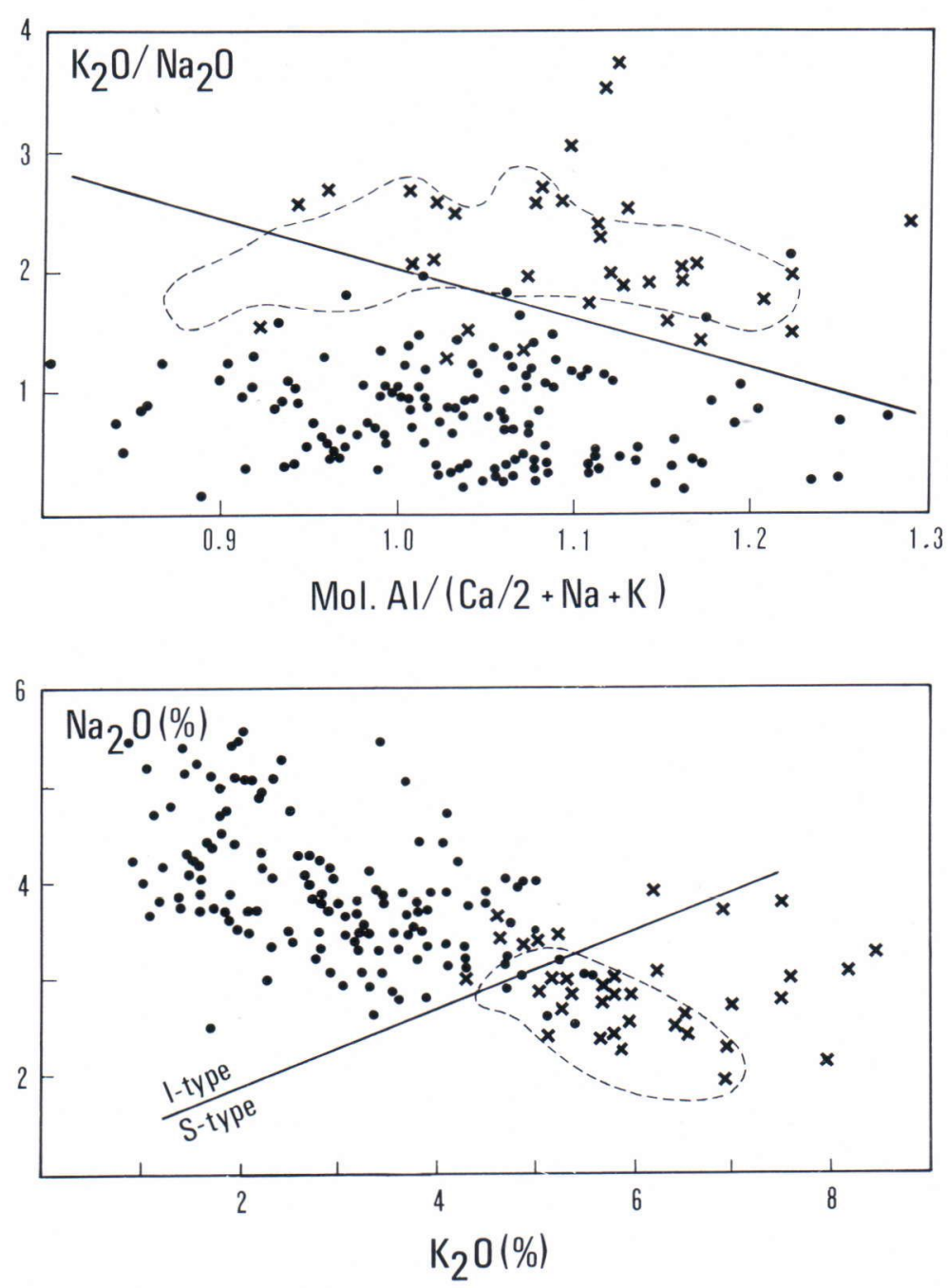

Fig. 5. Proterozoic granitoids from Finland in a $\mathrm{K} / \mathrm{Na}-\mathrm{mol}$. $\mathrm{Al} /(\mathrm{Ca} / 2+$ $\mathrm{Na}+\mathrm{K}$ ) diagram. Symbols and data sources as in Fig. 3. Erratic rapakivi granite analyses excluded (90\% within the field).

Fig. 6. Proterozoic granitoids from Finland in a $\mathrm{Na}_{2} \mathrm{O}-\mathrm{K}_{2} \mathrm{O}$ diagram. Symbols and data sources as in Fig. 3. The $\mathrm{I}-\mathrm{S}$ line is from White and Chappell (1983). Erratic rapakivi granite analyses excluded (95\% within the field). hanni 1984). The granitoids are calc-alkaline, although tonalitic rocks show calcic affinities (Fig. 3). The mol. $\mathrm{Al} /(\mathrm{Ca} / 2+\mathrm{Na}+\mathrm{K})$ ratios of the granitoids vary considerably (Fig. 4); the majority of them, however, have values under 1.1, corresponding to the I-type granitoids in Phanerozoic continental margins (Chappell and White 1974; Takahashi et al. 1981). Many of the higher values are due to high-Al tonalites (and trondhjemites) exhibiting low $\mathrm{K} / \mathrm{Na}$ ratios (Fig. 5). The $\mathrm{Na}_{2} \mathrm{O}$ is high compared with the $\mathrm{K}_{2} \mathrm{O}$ (Fig. 6); the $\mathrm{Na} / \mathrm{K}$ ratios are similar to those in the I-type granitoids of southeastern Australia (White and Chappell 1983).

The rare-earth element (REE) contents of the tonalites and trondhjemites seem to be systematically lower than those of granodiorites (Table 1). The REE patterns of both rock types, however, exhibit parallel trends (Fig. 7). The light REE (LREE) show a distinctly fractionated pattern, whereas the fractionation of the heavy REE (HREE) is not so clear. If present, the europium anomalies are weak $(\mathrm{Eu} / \mathrm{Sm}=0.21-0.31)$, except in the Uusikaupunki-Kalanti tonalite- 
Table 1. Rare earth element contents (in ppm) of selected Proterozoic granitoids in Finland. Analyses (except Arth et al., 1978) performed with the neutron activation method at the Reactor Laboratory of the Technical Research Centre of Finland. $\mathrm{N}=$ number of analyses. Major- and trace-element data and petrography of the granitoids are published in Vorma (1976), Arth et al. (1978), Nurmi (1983, 1984) and Nurmi et al. (1984).

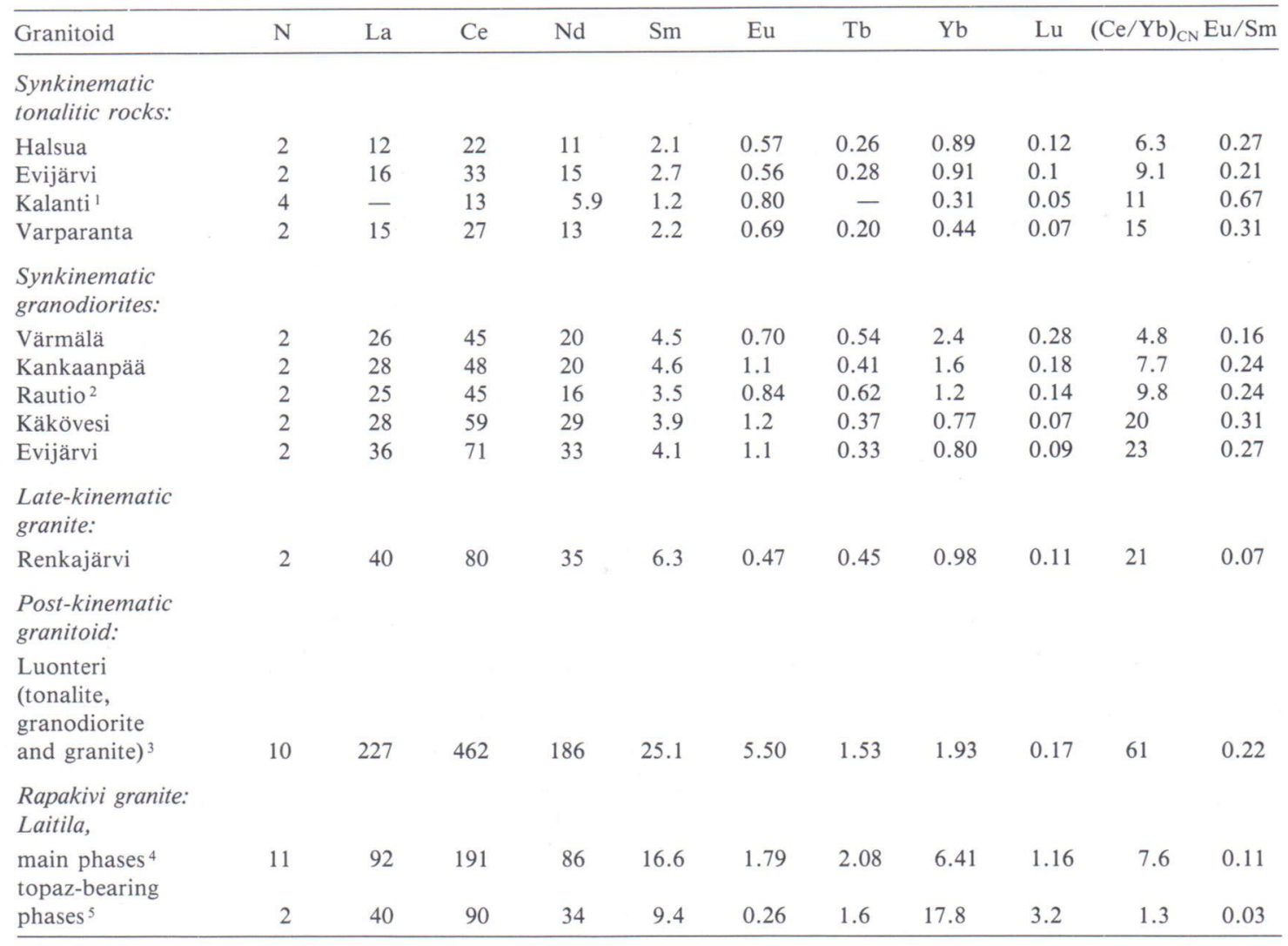

1 Arth et al. (1978)

2 Nurmi (1983)

3 Nurmi et al. (in preparation)

4 Vorma (1976)

5 Vorma (1976) and an unpublished analysis

trondhjemite suite, with its distinct positive anomaly $(\mathrm{Eu} / \mathrm{Sm}=0.67)$, and the Värmälä granodiorite, with its moderate negative anomaly $(\mathrm{Eu} / \mathrm{Sm}=0.16)$.

The sparse data on the granitoids in the complex of central Finland suggest that these rocks have evolved further than those in the schist belts, having, for example, a higher $\mathrm{SiO}_{2}, \mathrm{~K} / \mathrm{Na}$ and $\mathrm{Fe} / \mathrm{Mg}$, and a lower Sr value (Front 1985).

\section{Associated mineralization}

Sulphide mineralization, typically containing
Mo and $\mathrm{Cu}$, is known to be associated with the synkinematic granitoids in several localities (Fig. 8). Except for their small size, many of the occurrences have features in common with Phanerozoic porphyry deposits, and thus they have been termed porphyry type (Gaál and Isohanni 1979; Nurmi et al. 1984).

Porphyry-type mineralization is found in two geological settings. In the first they are associated with late phases of granodiorite complexes. The Mo-Cu occurrences of Luukkolansaari (Fig. 9) and Susineva are related to the late porphyritic 


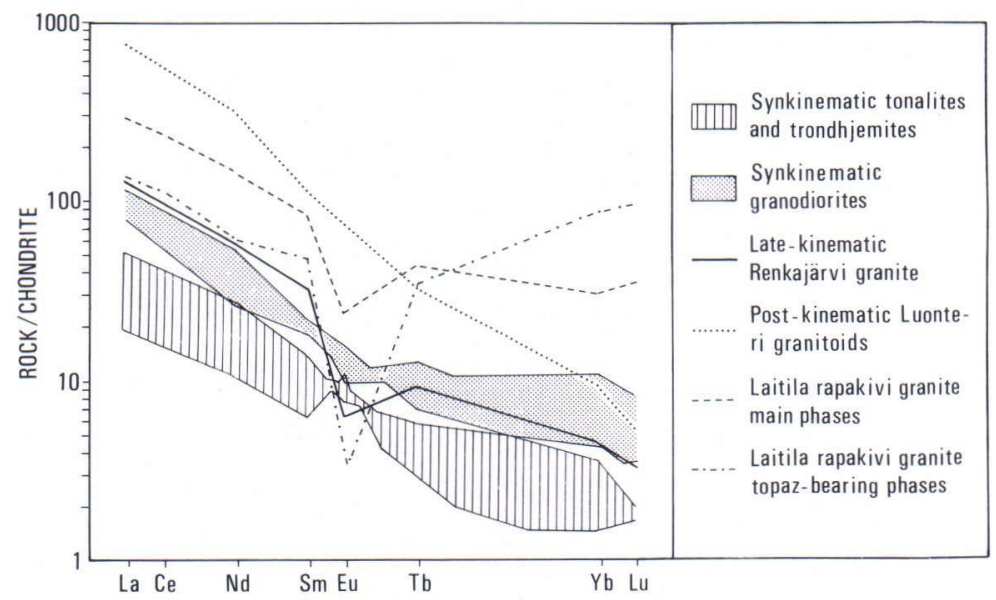

Fig. 7. Chondrite normalized rareearth element patterns of selected Proterozoic granitoids in Finland. Data as in Table 1. phases of composite granodiorite batholiths (Nurmi and Isohanni 1984; Nurmi 1985). The $\mathrm{Cu}-\mathrm{W}$-bearing tourmaline breccia at Ylöjärvi is genetically associated with the Hämeenkyrö granodiorite batholith as well but occurs in metavolcanic rocks just outside the pluton (Fig. 9). The second type of occurrence is associated with tonalite and trondhjemite intrusions, for example, a $0.6 \mathrm{~km} \times 2 \mathrm{~km}$ epizonal tonalite porphyry stock at Kopsa (Cu-Au) (Gaál and Isohanni 1979); a $6 \mathrm{~km} \times 7 \mathrm{~km}$ trondhjemite stock at Varparanta (Mo) (Nurmi et. al. 1984); and a large tonalite complex at Tienpää (Cu) (Nironen and Csongrádi 1984).

Five ore-element associations can be distinguished among the porphyry-type mineralizations on the basis of the principal ore-metal contents: $\mathrm{Mo}, \mathrm{Cu}, \mathrm{Mo}-\mathrm{Cu}, \mathrm{Cu}-\mathrm{Au}$ and $\mathrm{Cu}-\mathrm{W}$. In addition to molybdenite and chalcopyrite, the major ore minerals present in certain mineralizations are arsenopyrite, magnetite, pyrrhotite and scheelite (Inkinen 1984; Nurmi et al. 1984, Table 6). Ore minerals occur most commonly as fracture fillings, with or without quartz, forming stockworks or breccias; disseminations are less important. The mineralized fractures and veinlets are extensional or shear fractures in character.

The $\mathrm{Cu}-\mathrm{Au}$ occurrence of Kopsa comprises a stockwork of cross-cutting quartz veins and frac- tures with some disseminations (Gaál and Isohanni 1979). Mineralization is present as two gently dipping layers within the porphyry stock. The chalcopyrite zone is roughly $50 \mathrm{~m}$ thick and forms a gently curved basin $1,200 \mathrm{~m}$ long and $400 \mathrm{~m}$ wide. In the Tienpää area, chalcopyrite is concentrated in an area of $250 \mathrm{~m} \times 1,500 \mathrm{~m}$ in en echelon tension gashes controlled by a dextral shear zone (Nironen and Csongrádi 1984). The Mo occurrence of Varparanta has a very complex appearance. Molybdenite was deposited together with quartz in at least four stages during progressive deformation of a shear zone within the trondhjemite stock (Nurmi et al. 1984).

Breccia-type mineralization is exemplified by Vinnolinneva and Ylöjärvi. In the former, molybdenite occurs as pods and disseminations together with some chalcopyrite in a $200 \mathrm{~m} \times$ $1,600 \mathrm{~m}$ breccia zone within a quartz dioritic stock (Fig. 9). The breccia matrix is predominantly quartz, but tonalite porphyry, too, forms an intrusive breccia. The $\mathrm{Cu}-\mathrm{W}$ deposit of Ylöjärvi resembles the Phanerozoic tourmaline breccia pipes described from the porphyry-copper belt of Chile (e.g., Sillitoe and Sawkins 1971). Mineralization comprising arsenopyrite, chalcopyrite and scheelite is located in a quartz-tourmaline breccia and occurs as four parallel subvertical sheets in metavolcanic rocks (Himmi et al. 1979). The 


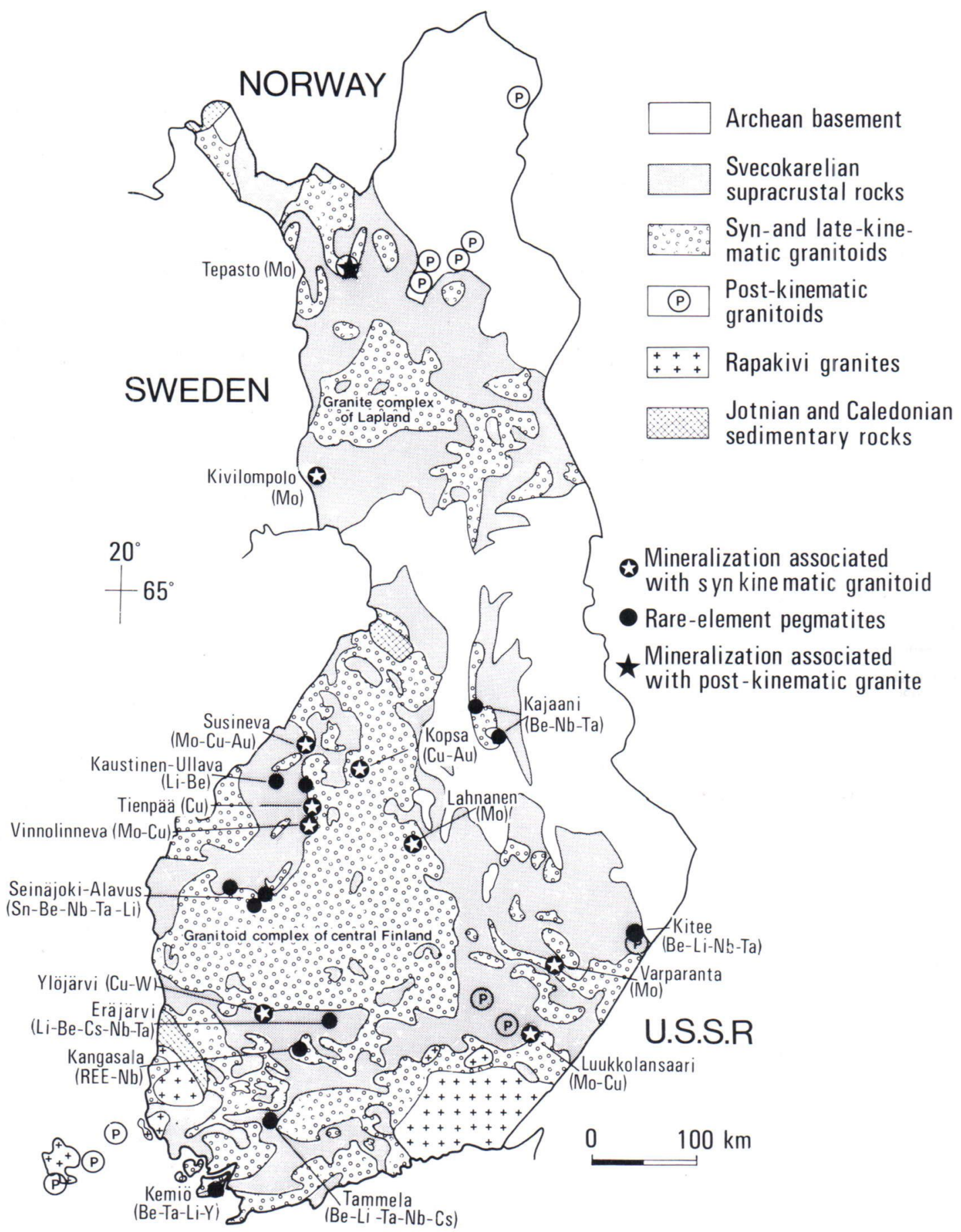

Fig. 8. The most important mineral occurrences associated with the Svecokarelian granitoids and the rare-element pegmatite districts in Finland. 

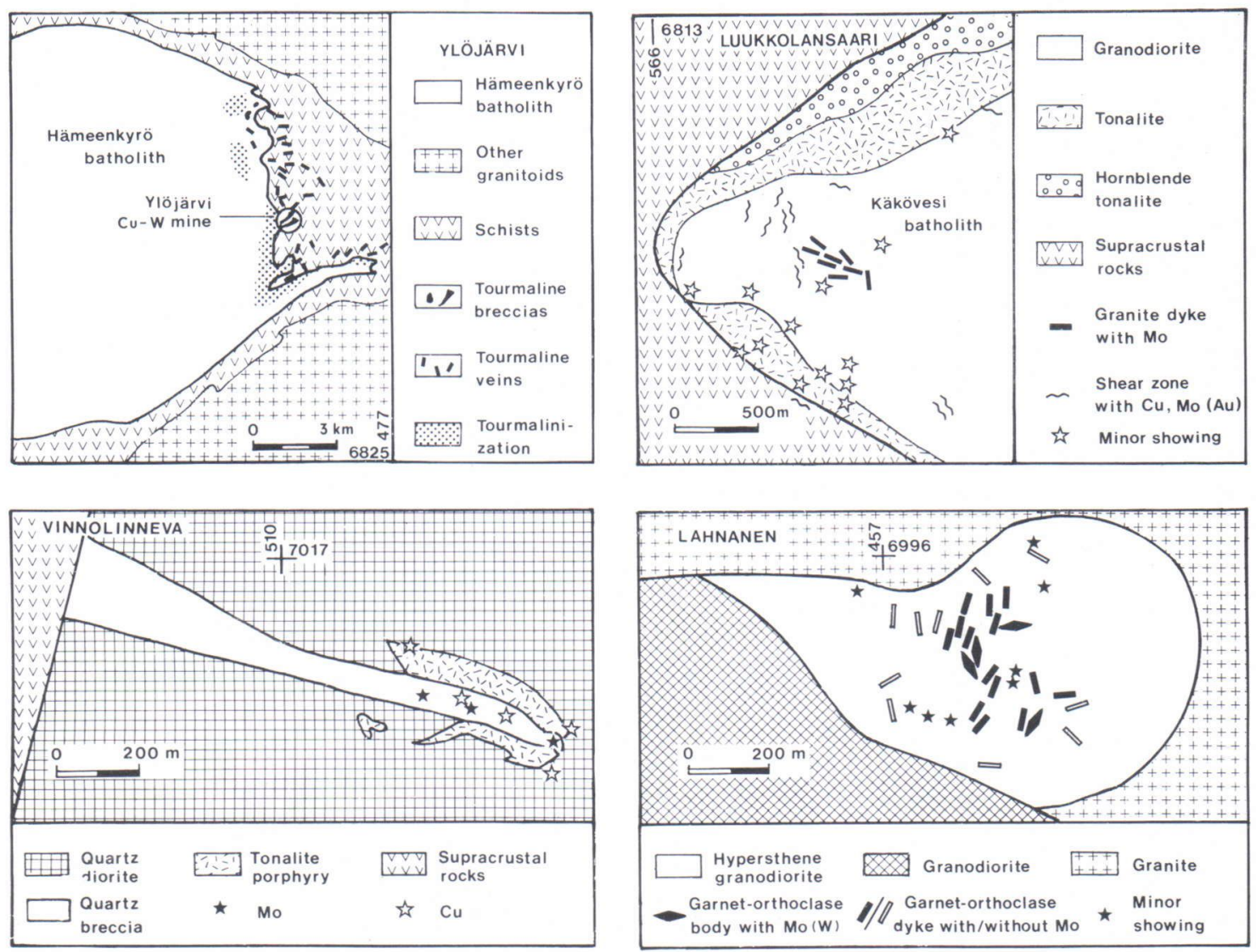

Fig. 9. Geological setting of selected Mo, Cu and $\mathrm{W}$ occurrences associated with the synkinematic Svecokarelian granitoids of Finland. Ylöjärvi modified from Gaál et al. (1981), others from Nurmi et al. (1984).

main zone is about $1 \mathrm{~km}$ long, $80 \mathrm{~m}$ broad and $300 \mathrm{~m}$ deep.

The Mo-Cu occurrences of Luukkolansaari and Susineva have certain similarities. Molybdenite is present as small pods and disseminations at the centres of the occurrences - in granite dykes at Luukkolansaari (Nurmi 1985) and in a granodiorite porphyry at Susineva (Nurmi and Isohanni 1984). Predominantly chalcopyrite mineralizations are spread in shear zones over larger areas at Luukkolansaari (Fig. 9). In the Susineva area, chalcopyrite, together with some molybdenite and gold, occurs in quartz veins and as breccia-like disseminations in the granodiorite surrounding the porphyry stock.

The Mo mineralization of Kivilompolo is located in deformed quartz veins within a migmatite belt (Yletyinen 1967). The genetic connection with granitoids is not known.

The style and intensity of the wall-rock alteration varies from one occurrence to another. The most common alteration phenomena are: propylitization, silicification, biotitization, sericitization and K-feldspathization (Inkinen 1984; Nurmi et al. 1984, Table 6). Minor prehnite veins are common. Tourmalinization and albitization are present in some occurrences. Alteration is usually exhibited as vein-veinlet alteration and selective alteration of particular minerals. Potassic alteration is revealed by the association: secondary quartz, biotite, K-feldspar and sericite. Biotite in recrystallized form or as an alteration product of 
hornblende shows the broadest halos. Typical propylitic minerals are epidote, chlorite, carbonate and albite as alteration products of plagioclase and biotite. Wall-rock alteration is usually marked only in the vicinity of fractures and veins. As an exception, conspicuous parts of the tonalite porphyry at Kopsa have undergone strong potassic and propylitic alterations (Gaál and Isohanni 1979; Nurmi 1985). Weak but widespread propylitization and biotitization are common around many occurrences. At Tienpää and Susineva, propylitization forms envelopes several hundreds of metres broad. The abundance of secondary minerals varies but in places reaches several percentages. The zoning in alteration patterns is usually poorly developed. In the Susineva occurrence, however, potassic alteration and ill-defined silicification are restricted to the granodiorite porphyry. Propylitization, together with sporadic albitization, predominates in the surroundings (Inkinen 1984; Nurmi and Isohanni 1984).

Lithogeochemical studies of the porphyry-type occurrences indicate that relatively extensive primary halos are associated with many of them (Nurmi 1984). Although the halo patterns are variable, they exhibit characteristic zoning (from the periphery to the core): $\mathrm{Zn}( \pm \mathrm{Pb})-$ $(\mathrm{Au} \pm \mathrm{Sb} \pm \mathrm{As})-\mathrm{Cu}( \pm \mathrm{S} \pm \mathrm{Ag})-\mathrm{K}( \pm \mathrm{Rb} \pm \mathrm{Rb} /$ $\mathrm{Sr} \pm \mathrm{Si})-\mathrm{Mo}$. Outside the mineralized areas, the host granitoids exhibit no geochemical specialization and cannot be distinguished from barren granitoids either in bulk geochemistry or average contents of ore metals. Even so, sporadic $\mathrm{Cu}$ as well as Mo, As, $\mathrm{K}$ and $\mathrm{Rb} / \mathrm{Sr}$ anomalies characterize many of the host intrusions.

The main differences between the porphyrytype occurrences described and Phanerozoic porphyry deposits are the small size of the former, their lack of pyritic and argillic halos and the weakness of their wall-rock alteration. The only deposit of economic importance so far discovered is the exhausted $\mathrm{Cu}-\mathrm{W}$ mine of Ylöjärvi (Himmi et al. 1979). Generally, Cu contents seem to be far too low (a few thousands ppm) from the economic point of view. The Au-, W- and Mo-bearing occurrences are more interesting. The average Au contents at Kopsa and Susineva are about $0.5 \mathrm{ppm}$, corresponding to those in Phanerozoic $\mathrm{Cu}$-Au porphyry deposits (Sillitoe 1979). At Kopsa, the reserves have been estimated at up to 25 million tonnes with $0.57 \mathrm{ppm} \mathrm{Au,} 4$ ppm Ag and $0.18 \% \mathrm{Cu}$ (Gaál and Isohanni 1979). Molybdenum contents of from 0.1 to over $1 \%$ are common in many showings (Nurmi et al. 1984, Table 6). However, even the biggest reserves measured are limited to a few tens of thousands of tonnes.

Several minor showings containing variable amounts of $\mathrm{Cu}$, As, $\mathrm{Mo}, \mathrm{Pb}, \mathrm{Zn}, \mathrm{W}$ and $\mathrm{Sn}$ are known to be associated with the granitoid complex of central Finland (Nurmi et al. 1984). The mineralization is typically composed of massive but thin veins controlled by shear fractures. Although the showings occur in granitoids, it is often difficult to relate them genetically with any particular intrusive phase. The ore mineral assemblages and wall-rock alteration patterns suggest a higher temperature than in porphyry-type mineralization. The Mo occurrence of Lahnanen is unique (Fig. 9), disseminated molybdenite being present in a hypersthene granodiorite stock in bodies and dykes composed mainly of orthoclase (70 to $90 \mathrm{vol}$. \%) and almandine garnet (Nurmi et al. 1984). Recently, sporadic wolframite and scheelite has also been met with (J. Nikander pers. comm., 1984).

\section{Late-kinematic granites}

\section{Geological and geochemical characteristics}

The areal extent of the late-kinematic granites is not yet known for sure, and hence they are not distinguished from the synkinematic granitoids in Fig. 1. Typically, the late-kinematic granites are closely associated with high-grade metamorphosed Svecokarelian mica gneisses and schists. They are especially widespread in the area south of the granitoid complex of central Finland. The 
granites either occur as diapiric domical bodies or form the neosome of migmatites common over large areas of the schist belts (Simonen 1960; Härme 1965; Korsman 1977; Korsman et al. 1984). Biotite-rich nebulitic remnants containing garnet and/or cordierite are common, as is the growth of K-feldspar porphyroblasts in the associated country rocks, thus demonstrating granitization (Härme 1965). The granites cross-cut the synkinematic granitoids.

The texture of the late-kinematic granites is non-foliated or weakly foliated, and pegmatitic varieties are common. The variation in composition is small, the rock type being monzogranite or syenogranite. No mafic or intermediate rocks are closely associated with the granites. The major minerals are microcline, quartz, plagioclase $\left(\mathrm{An}_{15-25}\right)$ and biotite, which is present only in small amounts (Simonen 1960). The accessory minerals include almandine garnet, cordierite, sillimanite, muscovite, zircon, apatite, tourmaline and opaques.

The granite complex of central Lapland (Fig. 1 ) is composed mainly of granites and migmatites, although its geology is poorly known. Recent dating of the granites gave slightly lower ages (ca. $1800 \mathrm{Ma}$ ) than those typical of late-kinematic granites. Field evidence suggests that these granites may represent a remobilized Presvecokarelian crust (Lauerma 1982).

Geochemically, the late-kinematic granites differ conspicuously from the synkinematic granitoids. The silica contents show a limited range, from 70 to $75 \%$ (Fig. 3). Nevertheless, the calcalkali ratio fluctuates markedly and some of the granites exhibit distinct alkaline affinities. The $\mathrm{K}_{2} \mathrm{O}$ contents are high (Fig. 6), and the $\mathrm{Na} / \mathrm{K}$ ratios (Fig. 5) and $\mathrm{CaO}$ contents low compared with the synkinematic granitoids. Although variable, the average $\mathrm{mol} . \mathrm{Al} /(\mathrm{Ca} / 2+\mathrm{Na}+\mathrm{K}) \mathrm{ra}-$ tios are higher than those in the synkinematic granitoids (Fig. 4).

The LREE contents of the late-kinematic twomica granite at Renkajärvi are slightly higher than those in the synkinematic granodiorites
(Table 1, Fig. 7). The fractionation of the REE is similar to the most fractionated granodiorites, but the Eu minimum is marked.

\section{Associated mineralization and rare-element pegmatites}

The late-kinematic granites are of minor metallogenic importance, only a few $\mathrm{U}$ showings and sparse molybdenite being known to occur in spatial association with them.

Granite pegmatites are widespread throughout the Svecokarelian complex. They are common, especially in close association with the latekinematic granites, but they are also found in association with the synkinematic granitoids. Pegmatites obviously of different ages occur in several areas, and it is often not possible to decide to which granite, if any, the pegmatites are genetically connected. In migmatite areas, many of the pegmatite dykes and lenses (often tourmaline-bearing) may be the result of partial melting of greywackes and other felsic schists and gneisses. It is well known that $\mathrm{H}_{2} \mathrm{O}, \mathrm{B}, \mathrm{Li}$ and $\mathrm{F}$ reduce the solidus temperature of granite magmas (e.g., Chorlton and Martin 1978; Stewart 1978; Manning 1982). Pegmatites enriched in these components may represent either the first partial melting of the metasedimentary and metavolcanic rocks enriched in these elements or the last magmatic residue after crystallization of granitic rocks (Stewart 1978). However, in several areas, the pegmatites are so closely related in space and time to the late-kinematic granites that some kind of genetic connection must exist.

Pegmatites enriched in rare-element minerals are concentrated in a few areas in the Svecokarelian region (Fig. 8, Table 2). Pegmatites containing beryl, $\mathrm{Nb}-\mathrm{Ta}$ oxides, $\mathrm{Li}$-minerals, $\mathrm{Mn}-\mathrm{Fe}$ phosphates, tourmaline and other rare-element minerals are found in Kemiö (Pehrman 1945; Lof and Hazebroek 1976), Tammela (Mäkinen 1913; Aurola 1963), Eräjärvi (Volborth 1954; Lahti 1981), Seinäjoki-Alavus (Haapala 1966, 1983) and Kitee (Kallio and Alviola 1974). In the 
Table 2. Localities of rare-element pegmatites in Finland and their most important elements.

\begin{tabular}{ll}
\hline Locality & Elements \\
\hline Kemiö & $\mathrm{Be}, \mathrm{Ta}, \mathrm{Li}, \mathrm{P}, \mathrm{Y}, \mathrm{B}$ \\
Tammela-Somero & $\mathrm{B}, \mathrm{Be}, \mathrm{Li}, \mathrm{Ta}, \mathrm{Nb}, \mathrm{Cs}$ \\
Eräjärvi & $\mathrm{B}, \mathrm{Be}, \mathrm{Nb}, \mathrm{Ta}, \mathrm{Li}, \mathrm{P}, \mathrm{Cs}, \mathrm{Sn}$ \\
Seinäjoki-Alavus & $\mathrm{B}, \mathrm{Be}, \mathrm{Sn}, \mathrm{Nb}, \mathrm{Ta}, \mathrm{Li}, \mathrm{P}$ \\
Kaustinen-Ullava & $\mathrm{Li}, \mathrm{Be}$ \\
Kitee-Tohmajärvi & $\mathrm{B}, \mathrm{Be}, \mathrm{Li}, \mathrm{P}, \mathrm{Nb}, \mathrm{T}, \mathrm{Sn}$ \\
Kajaani & $\mathrm{Be}, \mathrm{Nb}, \mathrm{Ta}$ \\
Kangasala & $\mathrm{REE}, \mathrm{Nb}$ \\
\hline
\end{tabular}

Kaustinen-Ullava area, pegmatite dykes containing an abundance of spodumene are found in greywacke schists. These pegmatites may represent significant reserves of $\mathrm{Li}$ : several dykes up to $25 \mathrm{~m}$ wide and several hundred metres long show an average of $1-1.2 \% \mathrm{Li}_{2} \mathrm{O}$. In the Kajaani area, pegmatites containing beryl and $\mathrm{Nb}$-Ta oxides are closely associated with the latekinematic granite batholith, which is about 1850 Ma old (Alviola 1977). The pegmatites of Kangasala are enclosed in a late-kinematic granite and contain allanite and a number of other REE minerals (Vorma et al. 1966). The pegmatites of the Eräjärvi and Kitee areas have radiometric $\mathrm{U}-\mathrm{Pb}$ ages of about $1780-1800 \mathrm{Ma}$, being roughly coeval with the late-kinematic granites. The pegmatites of the Seinäjoki area have recently been studied in detail because of their high cassiterite content. These pegmatites as well as many of the pegmatites of the Peräseinäjoki-Alavus area are characterized by marked tectonization, which is not typical of the late-kinematic granites (Haapala 1983).

\section{Post-kinematic granitoids}

\section{Geological and geochemical characteristics}

The granitoids of the post-kinematic group show only slightly lower ages than the late-kinematic granites, but have different geological and geochemical characteristics. The post-kinematic granitoids can be further divided into, two sub- groups, i.e., the granitoids in southern and in northern Finland (Fig. 1). The former are emplaced in Svecokarelian bedrock, whereas the latter are located within the Archean crust.

Post-kinematic granitoids have been met with at Åva, Lemland, Mosshaga and Seglinge in southwestern Finland (Vaasjoki 1977), and Petravaara (Nykänen 1968), Luonteri (Hirvensalo) (Korsman and Lehijärvi 1973) and Parkkila (Simonen 1982) in southeastern Finland. The intrusions are small, being only up to a few kilometres in diameter, and exhibit a composite character. Well-developed ring structures with ring and radial lamprophyre and granitic dykes occur in the Ava stock (Kaitaro 1953; Ehlers and Bergman 1984). The rock types in the postkinematic intrusions vary from quartz monzodiorite and tonalite to quartz monzonite, granodiorite and granite. The texture is non-foliated or shows igneous foliation, and the stocks have sharp or breccia contacts with the surrounding rocks, including the late-kinematic granites. The characteristic petrographic features are the abundance (up to several vol. \%) of sphene, apatite and magnetite, and the presence of fluorite and allanite in certain intrusive phases. Biotite may be relatively abundant in less evolved phases, which may contain also ferro-hastingsitic hornblende (Nurmi et al. in preparation). The K-feldspar is either orthoclase or microcline.

Geochemically, these granitoids differ markedly from other Svecokarelian granitoids in, for example, their high $\mathrm{FeO}, \mathrm{Fe} / \mathrm{Mg}, \mathrm{K}_{2} \mathrm{O}, \mathrm{TiO}_{2}$, $\mathrm{P}_{2} \mathrm{O}_{5}, \mathrm{Sr}, \mathrm{Sr} / \mathrm{Rb}, \mathrm{Ba}, \mathrm{Zn}$ and $\mathrm{F}$ (Pitkänen 1985; Nurmi et al. in preparation). The high $\mathrm{FeO}$, $\mathrm{TiO}_{2}, \mathrm{P}_{2} \mathrm{O}_{5}, \mathrm{Sr}$ and $\mathrm{Ba}$ also distinguish them from the rapakivi granites. The LREE contents of the Luonteri stock are very high (La over 700 times the chondritic values), the REE pattern is extremely fractionated $\left((\mathrm{Ce} / \mathrm{Yb})_{\mathrm{CN}}=61\right)$, and it exhibits no Eu anomalies (Table 1, Fig. 7). There are no major differences in the REE contents and patterns between the main intrusive phases (tonalite, granodiorite and granite), although the $\Sigma$ REE decreases towards the more evolved rocks. 
In northern Finland, the granites of the Nattanen type (Tepasto, Pomovaara, Riestovaara and Nattanen) and the Vainospää granite batholith are included in the post-kinematic age group (Patchett et al. 1981). Most, if not all, of them are emplaced in Presvecokarelian bedrock. Except for the generally foliated Vainospää granite, they occur as multiple batholiths and roundish stocks with sharp contacts and a non-foliated texture. No mafic or intermediate rocks are known to be associated with the plutons. However, granite is present in many texturally and evidently also geochemically variable intrusive phases.

The major minerals are plagioclase (oligoclase to albite), quartz and microcline. Chloritized biotite and muscovite occur as minor constituents, and sphene, apatite, zircon, allanite, magnetite and, occasionally, fluorite are present as accessory minerals (Mikkola 1928, 1941; Meriläinen 1976). Too few chemical analyses of the granites have yet been made to allow comparisons.

\section{Associated mineralization}

The post-kinematic granitoids seem to have potential for Mo deposits. In southern Finland, molybdenite has been found only as sparse disseminations in pegmatites associated with granitoids, in the granite of the Àva stock (V. Suominen, pers. comm. 1980) and in the granodiorite of the Luonteri stock (O. Kouvo, pers. comm. 1982).
More interesting showings are associated with the granites of the Nattanen type. Predominantly molybdenite mineralization has been met with in late-stage aplite granite from Tepasto. In the Juvoaivi stock, on the Soviet side of the border, molybdenite is known to occur in a breccia formed by a quartz-muscovite rock associated with an aplite granite dyke and abundant quartz veins (Dubrovsky 1965; see also Mikkola 1941).

At Tepasto, molybdenite is present together with some chalcopyrite as small disseminated rosettes throughout an aplite granite (Haapala 1983). The aplite granite occurs as a subhorizontal plate, some $200 \mathrm{~m}$ thick, obviously situated in the upper part of the stock and brecciating other granite varieties. The aplite granite is characterized by high $\mathrm{Rb}$ and $\mathrm{Ga}$, and low $\mathrm{Ba}$, $\mathrm{Sr}$ and $\mathrm{Zr}$. These features are similar to those in late-stage rapakivi granites, demonstrating advanced fractionation and superimposed alteration.

\section{Rapakivi granites}

\section{Geological and geochemical characteristics}

There are four large rapakivi granite batholiths (the Wiborg, Laitila, Vehmaa and Åland massifs) and several smaller satellitic batholiths and stocks (e.g., the Suomenniemi, Ahvenisto and Kökar massifs, and the Eurajoki and Kokemäki stocks) in southern Finland (Fig. 10). The group

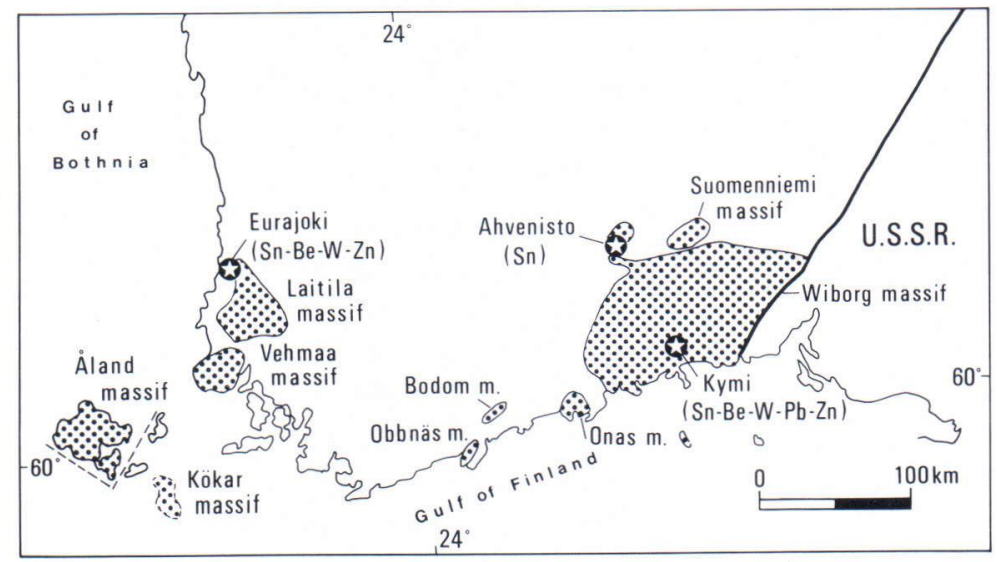

Fig. 10. The rapakivi granite plutons in southern Finland and associated mineralization. 
of rapakivi granites also includes a few smaller granitic intrusions (the Onas, Bodom and Obbnäs massifs) on the southern coast of Finland that do not show the typical rapakivi texture but have the same age and chemical characteristics as the ordinary rapakivi granites (e.g. Vaasjoki 1977; Törnroos 1984).

The rapakivi granite batholiths may be quite extensive (e.g., the Wiborg massif, which covers about $18,000 \mathrm{~km}^{2}$, and the Laitila massif, which covers about $1,400 \mathrm{~km}^{2}$ ), but the gravimetric data indicate that they are in fact large subhorizontal sheets (laccoliths) with roots $18-20 \mathrm{~km}$ deep (Lauren 1970). The massifs are epizonal multiple intrusions with sharp contacts against the migmatitic and metamorphic country rocks. Emplacement of the magmas produced thermometamorphic aureoles around the massifs (Vorma 1972). Volcanic equivalents (quartz porphyries, felsite porphyries) and porphyry dykes are found locally (Wahl 1925, 1947; Vorma 1975, 1976; Törnroos 1984). Also associated with the Wiborg and Ahvenisto massifs are minor anorthositic bodies; the olivine-tholeiite diabase dykes northwest of the Wiborg massif and in a roof pendant are of about the same age as the rapakivi granite (Laitakari 1969; Vorma 1975; Laitakari 1985).

The texture and mineralogy of the different rapakivi varieties in the various massifs have been described by Wahl (1925), Savolahti (1956), Simonen and Vorma (1969) and Vorma (1971, 1976). The granites of the earliest and main intrusive phases usually contain hornblende and biotite as dark constituents, often also fayalite and its alteration products. The K-feldspar is typically perthitic orthoclase, and the plagioclase andesine or oligoclase. The accessory minerals include fluorite, zircon, apatite, ilmenite, magnetite, allanite and anatase. In the various common biotite granites, alkali feldspar is more ordered, monazite occurs instead of allanite, and there are very few opaques. The latest intrusive phases are represented by microcline-albite granites with topaz as a characteristic minor constituent, and monazite, ilmenite, cassiterite and columbite as typical accessories (Haapala 1974, 1977 a). Also associated with these late-stage granites are topaz-bearing quartz-porphyry dykes.

The geochemistry of the rapakivi granites has been discussed in several papers (e.g., Sahama
Fig. 11. Rubidium-Ba-Sr diagram showing the trends of the Wiborg (triangles) and Laitila (crosses) rapakivi massifs, and fields of certain Svecokarelian synkinematic granitoids in Finland (dots) and the Renkajärvi latekinematic granite (shaded area). Data sources: Wiborg massif, Vorma (1971) and unpublished data; Laitila massif, Vorma (1976), Haapala (1977) and unpublished data; synkinematic granitoids, median contents of 42 granitoids from Nurmi (1984); and latekinematic Renkajärvi granite, 35 unpublished analyses.

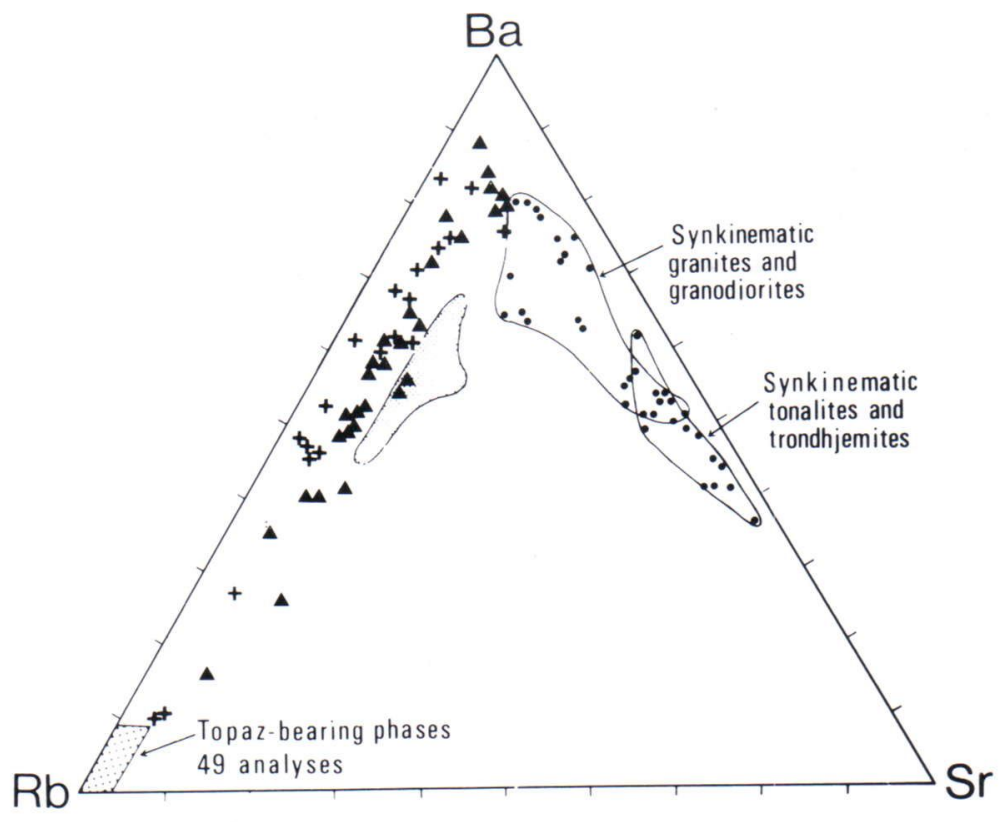


1945; Vorma 1976; Haapala 1977 a). The major element contents are fairly similar to those in the late-kinematic granites (Figs. 3, 5 and 6); the rapakivi granites are characterized by alkaline affinities, high $\mathrm{K} / \mathrm{Na}$ and variable $\mathrm{mol} . \mathrm{Al} /(\mathrm{Ca} / 2+$ $\mathrm{Na}+\mathrm{K}$ ) ratios. In contrast to the late-kinematic granites, the major and trace-element contents show a marked variation between the different rapakivi varieties. The generalized evolutionary trend, hornblende-biotite-fayalite granites normal rapakivi granites - biotite granites topaz-bearing granites, is marked by decreasing $\mathrm{Al}_{2} \mathrm{O}_{3}, \mathrm{FeO}, \mathrm{MgO}, \mathrm{CaO}, \mathrm{TiO}_{2}$ and $\mathrm{Mn}$ and increasing $\mathrm{SiO}_{2}$. By using the Harker and Niggli variation diagrams and the albite-orthoclasequartz diagrams, Vorma (1976) has shown that the compositional trends and mean compositions of the various rapakivi massifs differ clearly from each other. The geochemical evolution can be visualized particularly well in the trace-element diagrams of Ba-Sr-Rb and Zr-Ti (Figs. 11 and 12).

Rapakivi granites are typically enriched in trace elements such as F, Rb, Li, Zr, Hf, Th, U and REE (except Eu). The REE contents of the main phases of the Laitila massif are distinctly higher than those of the synkinematic and late-kinematic granites (Table 1, Fig. 7); the REE patterns show moderate fractionation $\left((\mathrm{Ce} / \mathrm{Yb})_{\mathrm{CN}}=7.6\right)$ and a distinct $\mathrm{Eu}$ minimum $(\mathrm{Eu} / \mathrm{Sm}=0.11)$. Topazbearing late-stage phases have a lower $\Sigma$ REE, very low $(\mathrm{Ce} / \mathrm{Yb})_{\mathrm{CN}}$ and very deep Eu minimum.

There are differences in radiometric U-Pb zircon ages between individual massifs and even between intrusive phases within the same massif (Vaasjoki 1977). The main parts of the plutons were emplaced as follows: the Wiborg massif $1700-1650 \mathrm{Ma}$ ago, the Åland massif $1670 \mathrm{Ma}$ ago, the Vehmaa massif $1590 \mathrm{Ma}$ ago, and the Laitila massif $1570 \mathrm{Ma}$ ago. The granites of the latest intrusive phases (some of them tin-bearing) give lower ages: $1640 \mathrm{Ma}$ in the Wiborg massif, $1620 \mathrm{Ma}$ in the Åland massif, and 1540-1500 $\mathrm{Ma}$ in the Laitila massif.

\section{Late-stage granites and associated mineralization}

In several areas tin and polymetallic mineralization are associated with the latest intrusive phases of the rapakivi granite batholiths and stocks, including all the large plutons (Haapala and Ojanperä 1972; Haapala 1977 a, 1977 b; Bergman 1981). These granites show the petrographic and geochemical pecularities typical of tin-bearing granites, and they differ markedly from normal rapakivi granites and other barren granites.

In texture, the late-stage granites are equigranular or porphyritic with angular megacrysts of microcline perthite and quartz in a fine-grained ground mass. They do not contain ovoidal $\mathrm{K}$-feldspar megacrysts typical of normal rapakivi granites. The major minerals, quartz, microcline and albite, occur in approximately equal amounts. The only dark constituent of these granites is $1-5$ vol. \% F-rich siderophyllite or lithian siderophyllite (protolithionite). Other very

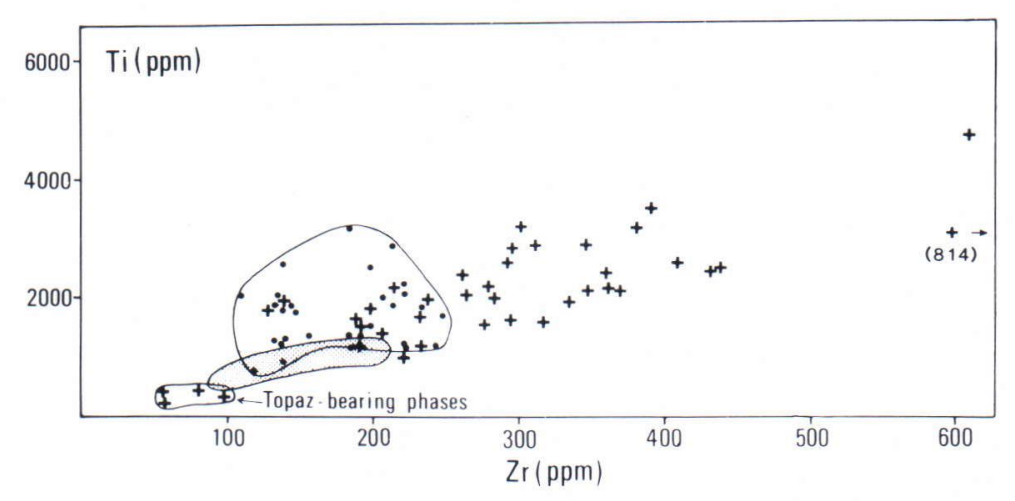

Fig. 12. Zirconium-Ti diagram showing the trend of the Laitila rapakivi massif (crosses) and fields of certain Svecokarelian syn-kinematic granitoids in Finland (dots) and latekinematic Renkajärvi granite (shaded area). Data sources: Laitila massif, Vorma (1976) and Haapala (1977); synkinematic granitoids, Ti from Nurmi (1984), Zr unpublished data; latekinematic Renkajärvi granite, 35 unpublished analyses. 
typical minor constituents are topaz and fluorite. Characteristic accessories are monazite, bastnaesite, ilmenite, cassiterite, columbite and thorite.

The topaz-bearing late-stage granites are peraluminous rocks characterized by extremely low $\mathrm{TiO}_{2}, \mathrm{MgO}, \mathrm{Ba}, \mathrm{Sr}$ and $\mathrm{Zr}$, and high F, $\mathrm{Li}, \mathrm{Ga}$, Rb, Sn and Nb (Figs. 11 and 12; Haapala 1974, 1977 a, 1983). They have undergone marked subsolidus reactions, as demonstrated by the presence of various exsolution and replacement textures (Haapala 1977 b). The alkali feldspar is typically vein and patch perthite. Rims of waterclear albite produced either by exsolution or, less probably, by metasomatic albitization occur between the alkali feldspar grains or between the alkali feldspar and turbid albite. The turbid albite contains very small secondary inclusions of fluorite, topaz, sericite and quartz produced by reactions between the anorthite molecule of the plagioclase and fluorine-bearing postmagmatic fluids (e.g., $\quad \mathrm{CaAl}_{2} \mathrm{Si}_{2} \mathrm{O}_{8}+4 \mathrm{HF}=\mathrm{CaF}_{2}+\mathrm{Al}_{2} \mathrm{~F}_{2} \mathrm{SiO}_{4}+$ $\mathrm{SiO}_{2}+2 \mathrm{H}_{2} \mathrm{O}$ ). The topaz is partly a primary mineral and partly clearly secondary. Other postmagmatic replacement reactions occurring in the autometamorphosed and greisenized granites are muscovitization and silicification of feldspars, albitization of K-feldspar, K-feldspathization of plagioclase, and muscovitization and chloritization of dark mica.

At least in the Eurajoki and Kymi areas (Figs. 10 and 13), the ore mineralization is related to cupolas of topaz-bearing granite. In the Eurajoki stock, cassiterite is found (1) as an accessory mineral in the topaz-bearing granite, (2) in pegmatite veins and pockets, and (3) in greisen veins. The composition of the cassiterite varies, depending on the type of occurrence (Haapala 1974, 1977 a). In both Eurajoki and the other areas, the greisen and quartz veins represent the most important type of mineralization, but all the occurrences found so far have been subeconomic.

The greisen and quartz veins that contain the ore minerals may occur in the topaz-bearing granites or in surrounding rocks no more than a few hundred metres from the contact (Fig. 13). The element association of the mineralization varies. Veins with $\mathrm{Sn}-\mathrm{Be}-\mathrm{W}-\mathrm{Zn}-\mathrm{Pb}-\mathrm{Cu}$ mineralization are found in the Eurajoki and Kymi areas (Haapala $1977 \mathrm{~b}$ ), whereas the recently discovered greisen bodies in the Ahvenisto massif (Fig. 10) are enriched in Sn (Peuraniemi et al. 1983). The beryllium minerals found in the greisen and quartz veins in the Eurajoki and Kymi areas are
Fig. 13. Geological setting of the Kymi mineralization associated with the Wiborg rapakivi granite massif.

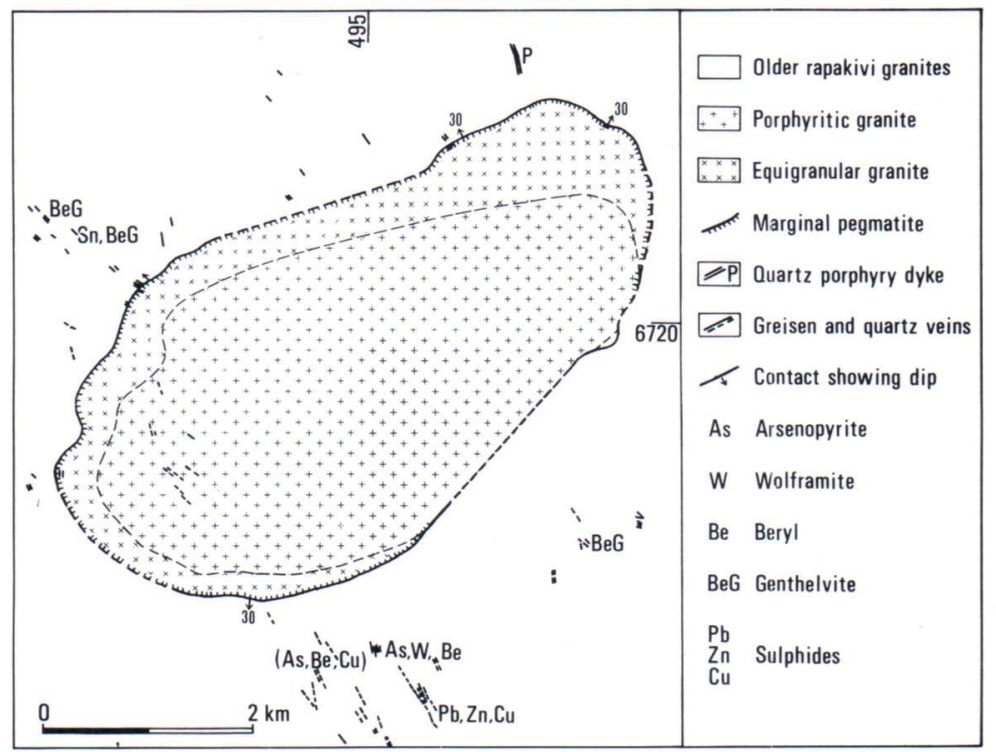


beryl, genthelvite and bertrandite (Haapala and Ojanperä, 1972).

Studies of fluid inclusions in the minerals of the greisen veins in the Eurajoki area show that the cassiterite crystallized from fluids at salinities of 3 to 17 wt $\% \mathrm{NaCl}$ equivalents and at minimum temperatures of $260^{\circ}$ to $390^{\circ} \mathrm{C}$, and the beryl from fluids at salinities of $11^{\circ}$ to $17 \mathrm{wt} \%$ $\mathrm{NaCl}$ equivalents and at minimum temperatures of $360^{\circ}$ to $410^{\circ} \mathrm{C}$ (Haapala and Kinnunen 1979).

\section{Discussion}

Chappell and White (1974) utilized a range of geochemical parameters to define specific granite types. Their classification of orogenic calc-alkaline granitoids into I- and S-types (Table 3) was later extended to include the M-type and anorogenic A-type (White 1979; Loiselle and Wones 1979). The granite types reflect differences in the genesis of the magmas. The I-type magmas were formed after partial remelting of mantle-derived material (White and Chappell 1977, 1983), whereas the M-type magmas, having a chemical and isotopic composition like that of the volcanic rocks of the island arcs, and occurring in close association with them, are related directly to partial melting of the oceanic slab or mantle (White 1979; Pitcher 1983). The S-type granites originated from sedimentary source rock in the crust. The A-type granites are characterized by alkaline affinities: low $\mathrm{CaO}, \mathrm{Al}_{2} \mathrm{O}_{3}, \mathrm{Ba}, \mathrm{Sr}, \mathrm{Eu}$ and transition metals (except $\mathrm{Zn}$ ), and high $\mathrm{SiO}_{2}, \mathrm{Fe} / \mathrm{Mg}$, $\mathrm{K} / \mathrm{Na}, \mathrm{F}, \mathrm{Ga}, \mathrm{Sn}, \mathrm{Zr}, \mathrm{Nb}, \mathrm{Ta}, \mathrm{Y}$ and REE (except Eu) (Loiselle and Wones 1979; Collins et al. 1982). The genesis of the A-type magmas has been related to partial melting of a felsic granulite, being a residue of previous orogenic granitoid magmas and enriched in refractory minerals (Collins et al. 1982; see also Loiselle and Wones 1979).

The granite types differ markedly in their potential for mineral deposits. Porphyry $\mathrm{Cu}$, Mo and Au deposits occur in I-type granites, whereas
Sn and W mineralizations are related to S-type granitoids (Chappell and White 1974; Beckinsale 1979; Ruitenberg and Fyffe 1982). M-type granitoids have a potential for porphyry $\mathrm{Cu}-\mathrm{Au}$ deposits (Pitcher 1983). In addition to the variable source of the magmas determining the initial concentrations of ore-forming elements (e.g., Plimer 1980; Ishihara 1981), another major reason for these differences may be the different oxygen fugacity of the magmas. This has a profound effect on the behaviour of S (Burnham and Ohmoto, 1980) and ore metals (e.g., Ishihara 1978; Sillitoe 1979). The metallogeny of A-type granites is less well known. Plimer (1983) suggests that Sn-W skarns, Mo-Bi veins, Sn greisens and porphyry Sn deposits are related to these granites, whereas Pitcher (1983) mentions columbite, cassiterite and fluorite mineralization in the same context.

The concept of granite types has been developed in Phanerozoic regions, particularly in southeastern Australia, but a few studies of Precambrian bedrock indicate that the classifications may be extended to Proterozoic granitoids (e.g., Wilson 1980; Nyström 1982).

\section{Synkinematic granitoids}

The Svecokarelian synkinematic granitoids of Finland exhibit I-type characteristics. They are calc-alkaline and vary widely in composition (Fig. 3). The ratios of $\mathrm{Na} / \mathrm{K}$ are high (Fig. 6) and those of mol. $\mathrm{Al} /(\mathrm{Ca} / 2+\mathrm{Na}+\mathrm{K})$ typically below 1.1 (Fig. 4). Hornblende, sphene and magnetite are commonly present, the latter indicating that the synkinematic granitoids also fulfil Ishihara's (1977) criteria for the magnetite series. Further, some of the granitoids contain porphyry-type mineralization.

A detailed discussion of REE geochemistry is not relevant here and would not, in any case, offer an unambiguous tool to aid petrogenetic interpretations. The REE contents and patterns are broadly similar to those in many calc-alkaline granitoids elsewhere (see e.g. Cullers and Graf 
Table 3. Characteristics of I- and S-type granites (Chappell and White 1974; Beckinsale 1979).

\begin{tabular}{|c|c|c|}
\hline & I-type & S-type \\
\hline Variation in composition & large & restricted, with high $\mathrm{SiO}_{2}$ \\
\hline Mol. $\mathrm{Al} /(\mathrm{Ca} / 2+\mathrm{Na}+\mathrm{K})$ & $<1.1$ & $>1.1$ \\
\hline $\mathrm{Na} / \mathrm{K}$ & high & low \\
\hline${ }^{87} \mathrm{Sr} /{ }^{86} \mathrm{Sr}$ & $<0.708$ & $>0.708$ \\
\hline$\delta^{18} \mathrm{O}$ & $6-10$ & $>10$ \\
\hline $\mathrm{f}\left(\mathrm{O}_{2}\right)$ in magma & high & low \\
\hline $\mathrm{Fe}^{3+} / \mathrm{Fe}^{2+}$ & high & low \\
\hline Typical minerals & $\begin{array}{l}\text { magnetite, sphene } \\
\text { hornblende }\end{array}$ & $\begin{array}{l}\text { ilmenite, muscovite } \\
\text { monazite, garnet, cordierite }\end{array}$ \\
\hline Associated mineralization & $\begin{array}{l}\text { porphyry-type } \\
\mathrm{Cu}, \mathrm{Mo}, \mathrm{Au}\end{array}$ & Sn, W \\
\hline
\end{tabular}

1984). The HREE depleted patterns may be attributed to the presence of minerals such as garnet, hornblende, pyroxene and plagioclase in the residue (e.g. Barker et al. 1976; Condie and McCrink 1982) or fractionation of, say, hornblende and plagioclase during crystallization (e.g., Arth et al. 1978; Frey et al. 1978; Condie and McCrink 1982). Several minor minerals present either in the residue or as crystallizing phases obviously have an important effect on the REE patterns of felsic magmas (Fourcade and Allegre 1981; Miller and Mittlefehldt 1982). The minor Eu anomalies in the granitoids do not necessarily exclude the role of plagioclase, because hornblende could have the opposite effect on the Eu, and thus prevent the development of a net anomaly in the melt. Moreover, in high oxygen fugacity magmas, the Eu can occur as $\mathrm{Eu}^{3+}$ and behave like the rest of the REE (Cullers and Graf 1984).

Viscosity being high in the granitoid magmas, complete separation of the minerals is impossible, contrary to what is assumed in most fractional crystallization models. Furthermore, the small proportion of potential parent basic-intermediate magmas and recognizable cumulates in relation to the voluminous silicic magmas argues against direct fractional crystallization models (e.g., Saunders et al. 1980). Hence many authors favour partial melting as the principal mechanism producing voluminous granitic magmas (White and Chappell 1977; Green 1980; Barker et al.
1981; Pitcher 1983; Othman et al. 1984). However, the Proterozoic tonalites of the Uusikaupunki-Kalanti area and northern New Mexico are very closely related to basic and intermediate rocks, including cumulus amphibolite and hornblendite (Arth et al. 1978; Condie and McCrink 1982). It is probable from field geology and petrogenetic modelling that these tonalites represent fractional crystallization products of tholeiitic basaltic magmas.

Fractional crystallization certainly operates to some degree during solidification of all granitoids. In the large granodiorite phase of the Rautio batholith this is indicated by geochemical zoning with more evolved rocks towards the centre (Nurmi 1983; Nurmi and Isohanni 1984). The REE contents decrease and the Eu minimum becomes more distinct in late-stage phases as a result of crystallization of hornblende, plagioclase and accessory minerals. Their fractionation occurred either in situ or during the ascent of the crystal mush.

Synkinematic tonalitic rocks have proved to be a more homogeneous group geochemically than granodiorites and granites (Nurmi 1984). This may indicate the more homogeneous source of the tonalites, which are possibly partial melts of a mafic source rock or differentiation products of basaltic magmas. On the other hand, the synkinematic granodiorites and granites may have originated from a more heterogeneous crustal source with variable hybriditization with mantle 
magmas. Besides magmatic rocks, recrystallized sedimentary rocks have been mapped as synkinematic granitoids in some areas.

The most primitive Svecokarelian granitoids are tonalites and trondhjemites with $\epsilon_{\mathrm{Nd}}$ values similar to early basalts and synkinematic gabbros $(+2$ to +3$)$, whereas the majority of the synkinematic granitoids have slighly lower $\epsilon_{\mathrm{Nd}}$ values $(-0.5$ to +1.5$)$ (Patchett et al. 1984). In this respect, the primitive tonalites resemble the M-type granites.

Initial ${ }^{87} \mathrm{Sr} /{ }^{86} \mathrm{Sr}$ determinations of the synkinematic granitoids are sparse but the available values are all low: 0.7021 from the Kalanti gabbrotrondhjemite suite (Arth et al. 1978), and 0.7030 from the granodiorites in Hämeenkyrö (Aro 1983) and Sottunga (Welin et al. 1983). Initial Hf isotope studies of the synkinematic plutonic rocks (four gabbros and a charnockitic granite) gave near chondritic values (Patchett et al. 1981). The roughly identical age of the Svecokarelian metavolcanic rocks, mafic plutonic rocks and synkinematic granitoids, and the close association of the last two in many plutons (e.g., Arth et al. 1978; Nurmi 1983) indicate that the rocks are cogenetic. Lead-isotopic studies of galenas from several Svecokarelian mineralizations do not show involvement of Archean $\mathrm{Pb}$ either (Vaasjoki 1981).

Recent Nd-isotope data demonstrate that the Svecokarelian crust in Finland does not have a major Archean component but that a new crust was generated during the Proterozoic (Patchett et al. 1984). However, a model with a minor Archean component $(<15 \%)$ in the granitoids is favoured to explain their $\epsilon_{\mathrm{Nd}}$ values, which are lower than in coeval mafic rocks (Patchett et al. 1984).

Analogous Nd-isotope characteristics prevail in the 1700-1900 Ma old Ketilidian crust of South Greenland (Patchett and Bridgwater 1984). Since the $\epsilon_{\mathrm{Nd}} \approx 0$ value appeared to be well-homogenized in the granitoids and no relicts of Archean crust have been identified from these areas, it is suggested that Archean material was added in the form of sediments transported to the orogenic zone on subducting ocean crust (Patchett and Bridgwater 1984; Patchett et al. 1984). In contrast the Phanerozoic Australian I-type granites have low and variable $\epsilon_{\mathrm{Nd}}$ values (from +0.4 to -8.9), which are attributed to the incorporation of mantle-derived crustal material very different in age (McCulloch and Chappell 1982).

An Andino-type plate-tectonic model with subduction from the southwest beneath the Archean basement was first proposed to explain the genesis of the Svecokarelian crust by Hietanen (1975). Her view has since been endorsed by Barker et al. (1981), Gaál (1982 a) and others. More complex models with several subduction zones have been proposed by Gaál (1982 b) and Bowes et al. (1984). Although there are problems in paleogeographical reconstructions of the plates, an Andino-type plate-tectonic model seems to be the most viable mechanism for Svecokarelian crust building. In addition to the I-type granites with porphyry-type mineralization, the massive sulphide deposits and their metavolcanic host rocks have many features in common with those in Phanerozoic continental margin environments (Rickard and Zweifel 1975; Rickard 1978; Lundberg 1980; Mäkelä 1980). The very short time span (some ten million years) within which the synkinematic igneous rocks formed the bulk of the extensive Proterozoic crust in Finland indicates that the process must have been more vigorous than that operating in present-day magmatic arcs. This may be due to the relatively small plates and the Earth's high heat production in the Proterozoic, resulting in more rapid plate movements than in modern times (Brown 1982).

\section{Late-kinematic granites}

The late-kinematic granites exhibit features typical of S-type granites. They have high and restricted silica contents, low $\mathrm{CaO}$ and $\mathrm{Na}_{2} \mathrm{O}$, and high $\mathrm{K}_{2} \mathrm{O}$ (Figs. 3 and 6). The average mol. $\mathrm{Al} /(\mathrm{Ca} / 2+\mathrm{Na}+\mathrm{K})$ ratios are higher than in the synkinematic granitoids but exhibit a wide varia- 
tion. No Sr-, Hf- or Nd-isotope determinations are available. However, the intimate association of the granites with mica gneisses and schists, the abundant nebulitic remnants composed of garnetiferous mica gneisses in some varieties and the common occurrence of accessory minerals such as garnet, cordierite, sillimanite and muscovite, which are typical of peraluminous granites (Clarke 1981), all suggest that the magmas derived from metasedimentary rocks.

The greywackes and shales all exhibit similar REE patterns, regardless of some variation in age (Nance and Taylor 1976). Model calculations show that about $40 \%$ melting of such greywackes under upper amphibolite or granulite facies conditions, leaving a residue composed of minerals such as plagioclase, hornblende, biotite, garnet, quartz, apatite and zircon, will produce REE patterns similar to those in the Renkajärvi granite (Fig. 7), albeit with slightly lower LREE contents and a weaker Eu minimum (Hanson 1980). However, reduction in the extent of melting will lead to higher LREE in the melt and a greater abundance of biotite in the residue. More plagioclase in the residue will evidently produce a more pronounced $\mathrm{Eu}$ minimum in the melt.

The late-kinematic granites usually have compositions near the "granite minimum» and very low contents of components such as $\mathrm{CaO}, \mathrm{MgO}$ and $\mathrm{TiO}_{2}$ (Simonen 1960). Experimental studies suggest that such granites represent relatively lowtemperature and $\mathrm{H}_{2} \mathrm{O}$-rich magmas (Clemens and Wall 1981). The magmas, enriched in water, caused advanced metasomatic changes in the surrounding rocks (Härme 1965). The very high $\mathrm{K}_{2} \mathrm{O}$ contents and consequently the low mol. $\mathrm{Al} /(\mathrm{Ca} / 2+\mathrm{Na}+\mathrm{K})$ ratios in certain granite samples may be attributed to secondary K-feldspar.

No volcanic rocks are known to be related to the late-kinematic granites, and evidently the volatile-rich magmas generally had little opportunity to rise markedly from their source area as diapiric plutons ( $c f$. Harris et al. 1970; Hyndman 1981). On the other hand, the Renkajärvi two- mica granite, which is homogeneous and rarely includes any enclaves, has ascended from its source. It has $\mathrm{K} / \mathrm{Na}$ ratios like those of the Australian S-type granites and mol. $\mathrm{Al} /(\mathrm{Ca} / 2+$ $\mathrm{Na}+\mathrm{K}$ ) ratios uniformly over 1.1 .

The formation of the late-kinematic granites marks the peak of Svecokarelian metamorphism between 1810 and $1850 \mathrm{Ma}$ ago under high temperature - low pressure conditions (Korsman 1977; Korsman et al. 1984). The end of this stage has been recorded by U-Pb dating of the sphenes and monazites in the synkinematic granitoids (Aho 1979; Simonen 1980).

Gaál (1982 a) demonstrates that the tectonic style changed during the Svecokarelian orogeny. The early stages were characterized by tight to isoclinal folding with different attitudes and thrusting. In the synkinematic migmatite complex of southern Finland, the major phases of tectonic and metamorphic activity and multiple neosome development have been found to have had a span of less than $20 \mathrm{Ma}$ (Hopgood et al. 1983). At the late-Svecokarelian stage (after $1850 \mathrm{Ma}$ ), the crust was sufficiently consolidated to allow a uniform regional stress field to generate large open upright folds with consistent NNE trends (Gaál 1982 a).

Late-kinematic metamorphism, tectonics and granites are all typical of Hercynian orogenic belts ( $c f$. Pitcher 1982), and the late-kinematic stage of the Svecokarelian orogeny has been regarded as of Hercyno type (Wilson 1982; see also Zwart 1967). It was evidently a consequence of thrusting inducing transverse shortening and thickening of the crust.

\section{Post-kinematic granitoids}

The post-kinematic granitoids of southern Finland exhibit unique characteristics and cannot be included unequivocally in any of the granite types. They have many features in common with rapakivi granites, for example, high $\mathrm{K} / \mathrm{Na}$, $\mathrm{Fe} / \mathrm{Mg}, \mathrm{Zr}$, and $\mathrm{F}$, but then they also have high $\mathrm{FeO}, \mathrm{TiO}_{2}, \mathrm{P}_{2} \mathrm{O}_{5}, \mathrm{Sr}$ and $\mathrm{Sr} / \mathrm{Rb}$. The extreme 
REE contents and patterns of the Luonteri stock (Table 1, Fig. 7) are similar to those of kimberlites (Mitchell and Brunfelt, 1974) and lamprophyres (Bachinski and Scott 1979; Paul and Potts 1981). Lamprophyres have been related genetically to magmas formed after a small degree of partial melting of undepleted mantle peridotite possibly followed by fractional crystallization or volatile transport (Bachinski and Scott 1979; Jahn et al. 1979; Paul and Potts 1981).

In southern Finland lamprophyres are intimately related with the Åva stock (Kaitaro 1953; Ehlers and Bergman 1984). Post-kinematic lamprophyres occur also in many other areas in the Svecokarelian comples (e.g., Huhma 1981; Neuvonen et al. 1981; Laukkanen 1985). Elsewhere, too, lamprophyres are often associated with postorogenic granitoids and mafic plutonic stocks (e.g. Bowes and McArthur 1976; Rock 1977; Jahn et al. 1979). Because many of the chemical characteristics of typical lamprophyres are also present in the post-kinematic granitoids (e.g., high $\mathrm{TiO}_{2}, \mathrm{P}_{2} \mathrm{O}_{5}, \mathrm{Sr}$, LREE and $\mathrm{Ce} / \mathrm{Yb}$ ), some kind of genetic connection is suggested between these rock types. Their source was probably in the mantle but variable crustal contamination was evidently involved in the evolution of the granitoid magmas. The initial ${ }^{87} \mathrm{Sr} /{ }^{86} \mathrm{Sr}$ ratio of the Mosshaga stock is 0.7032 and the initial $\epsilon_{\mathrm{Hf}}$ values of the Parkkila and Àva intrusion are +3.9 and +1.2 , respectively, also implying mantle source (Patchett et al. 1981; Welin et al. 1983).

Analogously, Thompson et al. (1984) postulate that certain syenites and their volcanic equivalents in southern Europe are fractionation residuums of minettes. The genesis of the ultrapotassic lamprophyres is related to post-collisional deep mantle magmatism.

The post-kinematic rocks are obviously related to deep faulting of the crust at the waning stage of the Svecokarelian orogeny and during the uplift of the crust. Faulting was also active in the Presvecokarelian basement area as evidenced by shear zones in eastern Finland (Bowes et al.
1984). In northern Finland, faulting possibly contributed to the formation of the post-kinematic granites. No mafic or intermediate rocks are exposed in association with these granites. However, quartz diorites, monzodiorites and lamprophyres are present in the Litsa-Araguba granite complex in the Kola Peninsula. The rocks are post-kinematic in age and occur in the same structural zone as the granites of the Nattanen type in eastern Lapland (Pushkarev et al. 1975; Vetrin et al. 1975). This suggests that the mantle magmas participated, at least as a heat source, in the formation of the granites. Yet, Archean granitoids were the major source of granites in northern Finland, as evidenced by all four isotopic systems: $\mathrm{Sr}, \mathrm{Nd}, \mathrm{Hf}$ and $\mathrm{Pb}$ (Patchett et al. 1981; Kouvo et al. 1983).

\section{Rapakivi granites}

The rapakivi granites of southern Finland are well-known examples of the world-wide group of anorogenic (or post-orogenic) Proterozoic granites characterized by the presence of varieties with rapakivi texture. Other representatives of this granite group are found in the Ukraine, Soviet Karelia, Sweden, southern Greenland, Labrador, Wisconsin, Missouri, Venezuela and Brazil (Bukharev et al. 1973; Gulson and Krogh 1975; Emslie 1978; Gaudette et al. 1978; Welin and Lundqvist 1984). In several areas, anorthosites and gabbros are closely associated with rapakivi granites, whose age varies between 1700 and $1300 \mathrm{Ma}$, usually being about $1500 \mathrm{Ma}$.

The rapakivi granites exhibit characteristics of A-type granites. They have alkaline affinities (Fig. 3) and are peraluminous to metaluminous with higher $\mathrm{SiO}_{2}, \mathrm{~K} / \mathrm{Na}$ (Fig. 5), Fe/Mg, $\mathrm{Rb}$ (Fig. 11), F, Li, Zr (Fig. 12), Hf, Th and U than orogenic granitoids. The $\mathrm{CaO}, \mathrm{P}_{2} \mathrm{O}_{5}$ and $\mathrm{Sr}$ (Fig. 11) are low. The late phases are also high in $\mathrm{Ga}, \mathrm{Nb}$ and $\mathrm{Sn}$ and extremely low in $\mathrm{MgO}$, $\mathrm{TiO}_{2}, \mathrm{Ba}, \mathrm{Sr}$ and $\mathrm{Zr}$ (Figs. 11 and 12). Greisentype $\mathrm{Sn}-\mathrm{Be}-\mathrm{W}$ and $\mathrm{Zn}-\mathrm{Cu}-\mathrm{Pb}$ sulphide mineralization is associated with certain late topazbearing phases. 
The REE contents and patterns in the main phases of the Laitila massif (Table 1, Fig. 7) are in good agreement with those of anorogenic granites in North America (Anderson 1983) and of A-type granites in southeastern Australia (Collins et al. 1982). The high REE contents in rapakivi granite magmas may be due to high $\mathrm{F}$ and alkali contents, because these elements can form stable high-coordination complexes with the REE in silicic melts (Collins et al. 1982). The ability of $\mathrm{Zr}$ to form complexes with alkalis may explain the increased solubility of zircon with the increasing alkaline affinities of granitic magmas (Watson 1979) and thus the high $\mathrm{Zr}$, Hf and HREE contents in rapakivi granites. Zircon tends to remain in the residue during the formation of calc-alkaline granitoids.

Both magmatic and metasomatic processes contributed to the development of the petrographic and geochemical pecularities of the late-stage granites. The occurrence of primary topaz in the granites indicates that the late-stage granite magmas were highly enriched in $\mathrm{F}$. The high $\mathrm{Nb}$ and Ta contents of the cassiterite occurring as an accessory mineral in the topaz-bearing granites points strongly to the primary magmatic origin of that cassiterite, reflecting the elevated Sn content of the magma (Haapala 1977 a). Obviously, several other trace elements were also enriched in the volatile-rich residual magma. The experimental studies by Kovalenko (1973) and Manning (1982) show that the addition of fluorine lowers the viscosity and crystallization temperature, and shifts the isobaric minimum towards albite-richer compositions in the granite $-\mathrm{H}_{2} \mathrm{O}$ system. Thus, the somewhat increased $\mathrm{Na} / \mathrm{K}$ ratio in the topazbearing granites may be due to the high $\mathrm{F}$ contents of the late-stage magmas. But certain replacement reactions (e.g., the growth of secondary topaz and quartz, the replacement reactions along fractures) clearly indicate metasomatism. Certain ion-exchange reactions can obviously take place between the postmagmatic fluids and the minerals of the granite without the development of ordinary replacement textures. The anomalously high $\mathrm{Rb}$ content and low $\mathrm{Ba}$ content (both mobile elements) of the K-feldspar and granite (Fig. 11) could be attributed to postmagmatic fluid-rock interactions alone. On the other hand, the same evolutionary trend (hornblendebiotite-fayalite granite - normal rapakivi granites - biotite granite - topaz-bearing granite) is also indicated by the immobile elements $\mathrm{Zr}$ and Ti (Fig. 12), demonstrating the ability of fractional crystallization to operate in these lowviscosity granite magmas.

The REE contents of the late phases of the Laitila massif (Table 1, Fig. 7) cannot be due merely to fractional crystallization. The LREE are considerably lower than in the main phases, principally because of fractionation of accessory phases such as monazite, apatite and allanite. In contrast, the HREE are higher in the late phases. This is unexpected, because zircon is almost totally fractionated before the crystallization of the late phases. The $\mathrm{Zr}$ contents drop from 250$430 \mathrm{ppm}$ in the main phases to $<40-150 \mathrm{ppm}$ in the late phases (Fig. 12). Zircon has very high partition coefficients for the HREE in that they progressively increase towards Lu (Nagasawa 1970). Thus, in the late phases, the behaviour of the HREE patterns and contents should be the exact opposite if only fractional crystallization is involved.

However, the HREE are able to form stable complexes in fluids enriched in $\mathrm{F}^{-}, \mathrm{Cl}^{-}$and $\mathrm{CO}_{3}^{2-}$ (Mineyev 1963; Kerrich and Fryer 1979; Alderton et al. 1980). In the Kazakhstan massif, the REE were obviously transported as alkalifluoride complexes (Mineyev 1963). Since the LREE complexes are less stable than the HREE complexes, the residual fluids were enriched in HREE. Precipitation of the REE started when the alkali content of the fluids began to decrease, and the HREE were enriched in high-F rocks, as in the Laitila massif. The deep Eu anomalies in the late phases may be due partly to post-magmatic albitization of the plagioclase ( $c f$., Fowler and Doig 1983). Alteration can also explain the very 
low $\mathrm{Sr}$ contents of the late phases ( $c f$., Taylor 1965; Lawrence 1975).

Hafnium-isotope studies with $\epsilon_{\mathrm{Hf}}$ values from 0 to +3.3 suggest mantle/lower crust genesis for the rapakivi magmas (Patchett et al. 1981). Associated gabbro-anorthosites and olivine-tholeiite diabases evidently represent the mantle component of this bimodal magmatism. As for voluminous granite magmas, the involvement of a significant crustal component in their source seems mandatory (e.g., Wyllie et al. 1976); the mantle magmas probably initiated major partial melting in the lower crust (e.g., Bridgwater et al. 1974; Emslie 1978). The source of the rapakivi granite magmas may have been either calc-alkaline igneous rocks (Anderson 1983) or preferably a felsic granulite, the residue of previous orogenic magmas, as supposed by Emslie (1980) and Collins et al. (1982) in case of the rapakivi granites in North America and the Australian A-type granites, respectively. Vorma (1976) has concluded that the rapakivi magmas were generated by ultrametamorphism of the lower crust under the conditions of intermediate to high-pressure

Table 4. Summary of the characteristics of Proterozoic granitoids in Finland.

\begin{tabular}{|c|c|c|c|c|}
\hline $\begin{array}{l}\text { Group and } \\
\text { age }(\mathrm{Ma})\end{array}$ & $\begin{array}{l}\text { Mode of } \\
\text { occurrence }\end{array}$ & Granitoids $^{1}$ & $\begin{array}{l}\text { Cogenetic }{ }^{1} \\
\text { rocks }\end{array}$ & $\begin{array}{l}\text { Characteristic } \\
\text { minerals }\end{array}$ \\
\hline \multirow[t]{2}{*}{$\begin{array}{l}\text { Syn- } \\
\text { kinematic } \\
\text { granitoids } \\
1860-1930\end{array}$} & $\begin{array}{l}\text { composite } \\
\text { batholiths } \\
\& \text { stocks } \\
\text { in schist } \\
\text { belts }\end{array}$ & $\begin{array}{l}\text { granodiorite, } \\
\text { tonalite, } \\
\text { trondhjemite, } \\
\text { granite, } \\
\text { charnockite }\end{array}$ & $\begin{array}{l}\text { metavolcanic } \\
\& \text { mafic to } \\
\text { intermed. } \\
\text { plutonic } \\
\text { rocks }\end{array}$ & $\begin{array}{l}\text { biotite, } \\
\text { hornblende, } \\
\text { sphene, } \\
\text { magnetite, } \\
\text { hypersthene }\end{array}$ \\
\hline & $\begin{array}{l}\text { granitoid } \\
\text { complex of } \\
\text { central } \\
\text { Finland }\end{array}$ & $\begin{array}{l}\text { granodiorite, } \\
\text { granite, } \\
\text { tonalite } \\
\text { charnockite }\end{array}$ & $\begin{array}{l}\text { mafic to } \\
\text { intermed. } \\
\text { plutonic } \\
\text { rocks }\end{array}$ & $\begin{array}{l}\text { biotite, } \\
\text { sphene, } \\
\text { magnetite, } \\
\text { hypersthene }\end{array}$ \\
\hline $\begin{array}{l}\text { Late- } \\
\text { kinematic } \\
\text { granites } \\
1800-1850\end{array}$ & $\begin{array}{l}\text { plutons \& } \\
\text { migmatite- } \\
\text { forming } \\
\text { bodies }\end{array}$ & $\begin{array}{l}\text { monzo- } \\
\& \text { syeno- } \\
\text { granite, } \\
\text { pegmatites }\end{array}$ & - & $\begin{array}{l}\text { biotite, } \\
\text { garnet, } \\
\text { cordierite, } \\
\text { sillimanite, } \\
\text { muscovite }\end{array}$ \\
\hline \multirow[t]{2}{*}{$\begin{array}{l}\text { Post- } \\
\text { kinematic } \\
\text { granitoids } \\
\text { ca. } 1800\end{array}$} & $\begin{array}{l}\text { composite } \\
\text { stocks \& } \\
\text { ring dykes } \\
\text { in } \\
\text { S Finland }\end{array}$ & $\begin{array}{l}\text { granite, } \\
\text { granodiorite, } \\
\text { tonalite, } \\
\text { granitic } \\
\text { dykes }\end{array}$ & $\begin{array}{l}\text { quartz } \\
\text { monzodiorite } \\
\& \text {-monzonite, } \\
\text { lamprophyres }\end{array}$ & $\begin{array}{l}\text { biotite, } \\
\text { sphene, } \\
\text { apatite, } \\
\text { hornblende, } \\
\text { magnetite, } \\
\text { fluorite, } \\
\text { allanite }\end{array}$ \\
\hline & $\begin{array}{l}\text { multiple } \\
\text { batholiths } \\
\& \text { stocks in } \\
\text { N Finland }\end{array}$ & $\begin{array}{l}\text { granites in } \\
\text { texturally } \\
\text { variable } \\
\text { forms }\end{array}$ & - & $\begin{array}{l}\text { biotite, } \\
\text { sphene, } \\
\text { magnetite, } \\
\text { fluorite, } \\
\text { allanite }\end{array}$ \\
\hline $\begin{array}{l}\text { Rapakivi } \\
\text { granites } \\
1540-1700\end{array}$ & $\begin{array}{l}\text { multiple } \\
\text { batholiths } \\
\text { \& stocks in } \\
\text { S Finland }\end{array}$ & $\begin{array}{l}\text { granites in } \\
\text { texturally } \\
\text { variable } \\
\text { forms }\end{array}$ & $\begin{array}{l}\text { gabbro, } \\
\text { anorthosite, } \\
\text { diabase, } \\
\text { felsic } \\
\text { volcanic } \\
\text { \& porphyritic } \\
\text { dyke rocks }\end{array}$ & $\begin{array}{l}\text { orthoclase, } \\
\text { biotite, } \\
\text { hornblende, } \\
\text { fayalite, } \\
\text { fluorite, } \\
\text { allanite, } \\
\text { anatase, } \\
\text { monazite }\end{array}$ \\
\hline
\end{tabular}

\footnotetext{
1 Plutonic rocks named according to the scheme recommended by the IUGS (Streckeisen 1974).
} 
granulite facies during the culmination stage of the Svecokarelian orogeny and emplaced during the distensional post-orogenic stage.

Neodymium-Sm studies of anorogenic granites ca. 1400 Ma old in Wyoming and Colorado suggest a heterogeneous Proterozoic crustal source with a model age of 1800 Ma (DePaolo 1981; Nelson and DePaolo 1982). The high ${ }^{87} \mathrm{Sr} /{ }^{86} \mathrm{Sr}$ initial ratios of many rapakivi granites in North America, Sweden and Soviet Karelia (Emslie 1978; Wilson 1980; Rub et al. 1982; Anderson 1983) may imply a crustal source or post-magmatic resetting of $\mathrm{Sr}$ isotopes (Welin and Lundqvist 1984).

The voluminous rapakivi granites and associated mafic rocks obviously indicate post-orogenic rifting of the consolidated and uplifted Svecokarelian crust ca. $1700 \mathrm{Ma}$ ago. The diabase dykes with glassy apophyses and amygdules demonstrate that no significant erosion or thermal activity has affected the crust since their intrusion (Lindqvist and Laitakari 1980). The waning of the principal uplift stage of the Svecokarelian crust can be inferred from the K-Ar biotite ages,

\begin{tabular}{|c|c|c|c|}
\hline $\begin{array}{l}\text { Geochemical } \\
\text { characteristics }\end{array}$ & $\begin{array}{l}\text { Associated } \\
\text { mineralization }\end{array}$ & $\begin{array}{l}\text { Granite } \\
\text { type }\end{array}$ & $\begin{array}{l}\text { Genetic } \\
\text { considerations }\end{array}$ \\
\hline $\begin{array}{l}\text { calc-alkaline (tonalites have cal- } \\
\text { cic affinities); generally metalu- } \\
\text { minous; variable } \mathrm{SiO}_{2} \text {, low } \\
\mathrm{K} / \mathrm{Na} ;{ }^{87} \mathrm{Sr} /{ }^{86} \mathrm{Sr} \leq 0.7030 \\
\epsilon_{\mathrm{Nd}} \approx 0 ;(\mathrm{Ce} / \mathrm{Yb})_{\mathrm{CN}}=5-23 \\
\mathrm{Ce}: 45-71 \mathrm{ppm} \text { in granodiorites, } \\
13-33 \text { ppm in tonalites }\end{array}$ & $\begin{array}{l}\text { porphyry-type } \mathrm{Mo}, \mathrm{Cu} \text {, } \\
\mathrm{Mo-Cu}, \mathrm{Cu}-\mathrm{Au}, \mathrm{Cu}-\mathrm{W} \\
\text { assoc. with non- } \\
\text { specialized late phases }\end{array}$ & I-type & $\begin{array}{l}\text { subduction-related mantle } \\
\text { magmas acted as indirect } \\
\text { (heat) and direct sources, } \\
\text { granitoids represent newly } \\
\text { mantle-derived material } \\
\text { but recycling in the crust } \\
\text { is evident }\end{array}$ \\
\hline $\begin{array}{l}\text { generally higher } \mathrm{SiO}_{2}, \mathrm{Fe} / \mathrm{Mg} ; \\
\mathrm{K} / \mathrm{Na} \text { lower } \mathrm{Sr}\end{array}$ & $\begin{array}{l}\text { Minor } \mathrm{Cu}, \mathrm{As}, \mathrm{Mo}, \mathrm{Zn} \\
\mathrm{Pb}, \mathrm{W}, \mathrm{Sn}\end{array}$ & I-type & $\begin{array}{l}\text { may represent deeper level } \\
\text { of the crust }\end{array}$ \\
\hline $\begin{array}{l}\text { alkaline affinities; high } \mathrm{SiO}_{2} \text {, } \\
\mathrm{K} / \mathrm{Na}, \mathrm{Rb} \text {; low } \mathrm{CaO}, \mathrm{FeO}, \\
\mathrm{MgO}, \mathrm{Ti}, \mathrm{Sr}, \mathrm{Zr}, \mathrm{Eu}\end{array}$ & $\begin{array}{l}\text { rare-element pegmatites; } \\
\text { minor Mo, U }\end{array}$ & S-type & $\begin{array}{l}\text { partial melting and graniti- } \\
\text { zation of supracrustal } \\
\text { rocks during } \\
\text { high-T low-P metamor- } \\
\text { phism in thickened crust }\end{array}$ \\
\hline $\begin{array}{l}\text { alkaline affinities; high } \mathrm{K} / \mathrm{Na} \text {, } \\
\mathrm{FeO}, \mathrm{Fe} / \mathrm{Mg}, \mathrm{Ti}, \mathrm{P}, \mathrm{Sr}, \mathrm{Sr} / \mathrm{Rb}, \\
\mathrm{Zn}, \mathrm{F}, \mathrm{LREE}, \mathrm{Ce} / \mathrm{Yb} ; \\
\epsilon_{\mathrm{Hi}} \approx 1-4 ;{ }^{87} \mathrm{Sr} /{ }^{86} \mathrm{Sr} \approx 0.7030\end{array}$ & - & - & $\begin{array}{l}\text { fractionation of alkalic } \\
\text { basic magmas with } \\
\text { variable crustal } \\
\text { contamination; mantle } \\
\text { magmatism initiated } \\
\text { by deep faulting }\end{array}$ \\
\hline $\begin{array}{l}{ }^{87} \mathrm{Sr} /{ }^{86} \mathrm{Sr}=0.7088-0.7117 ; \\
\epsilon_{\mathrm{Nd}} \approx-8 ; \epsilon_{\mathrm{Hf}}=-(10-12) ; \\
{ }^{207} \mathrm{~Pb} /{ }^{204} \mathrm{~Pb}_{\mathrm{Kfs}}=14.8-15.0 \\
{ }^{206} \mathrm{~Pb} /{ }^{204} \mathrm{~Pb}_{\mathrm{Kfs}}=14.6\end{array}$ & $\begin{array}{l}\text { disseminated } \mathrm{Mo}(\mathrm{Cu}) \\
\text { in leucogranites }\end{array}$ & - & $\begin{array}{l}\text { remelting of Archean } \\
\text { crust, possibly initiated by } \\
\text { mantle magmas and deep } \\
\text { faulting }\end{array}$ \\
\hline
\end{tabular}

\begin{tabular}{|c|c|c|c|}
\hline $\begin{array}{l}\text { alkaline affinities; metaluminous } \\
\text { to peraluminous; high } \mathrm{SiO}_{2} \text {, } \\
\mathrm{K} / \mathrm{Na}, \mathrm{Fe} / \mathrm{Mg}, \mathrm{Rb}, \mathrm{Li}, \mathrm{F} \text {, } \\
\mathrm{Zr}, \mathrm{Hf}, \mathrm{REE}(\text { except Eu); } \\
\text { low } \mathrm{P}, \mathrm{Sr}, \mathrm{Eu} ; \epsilon_{\mathrm{Hf}}=\end{array}$ & $\begin{array}{l}\mathrm{Sn}, \mathrm{W}, \mathrm{Be}, \mathrm{Zn}, \mathrm{Pb} \\
\text { in greisen \& quartz } \\
\text { veins assoc. with } \\
\text { specialized leuco- } \\
\text { granites }\end{array}$ & A-type & $\begin{array}{l}\text { remelting of granulitic } \\
\text { lower crust, initiated } \\
\text { by mantle magmas related } \\
\text { to intracontinental } \\
\text { rifting }\end{array}$ \\
\hline
\end{tabular}

$0-3.3$ 
which are grouped around $1750 \mathrm{Ma}$ in gneisses and $1720 \mathrm{Ma}$ in migmatite areas of eastern Finland (Korsman et al. 1984). According to Patchett and Bridgwater (1984), cooling from above $\mathrm{K}-\mathrm{Ar}$ and $\mathrm{Rb}-\mathrm{Sr}$ biotite blocking temperatures around $1700 \mathrm{Ma}$ ago is a feature common to all 1700 - 1900 Ma old crust in the northern hemisphere.

The Jotnian red sandstones and diabase dykes occurring in a down-faulted block in spatial association with the Laitila massif (Fig. 1) are evidently indications of sedimentation and later magmatic activity in a rift zone. The Jotnian shales have been dated tentatively at 1300 to 1400 $\mathrm{Ma}$ by the $\mathrm{K}-\mathrm{Ar}$ and $\mathrm{Rb}-\mathrm{Sr}$ methods, and the diabase dykes at 1260-1270 Ma (Simonen 1980; Patchett et al. 1981). A similar association of anorogenic rapakivi granites - anorthosites and continental sandstone - basalt sequence is typical in North America, Greenland and the Ukraine (see Emslie 1978). Emslie (1978) suggests that the rapakivi granites - anorthosites signalled the beginning of the activity in the mantle that eventually matured into continental rifting.

\section{Conclusions}

Selected characteristics of the granitoids are summarized in Table 4. Despite the gaps in ge-

\section{References}

Aho, L., 1979. Petrogenetic and geochronological studies of metavolcanic rocks and associated granitoids in the Pihtipudas area, Central Finland. Geol. Surv. Finl., Bull. 300, $22 \mathrm{p}$.

Alderton, D. H. M; Pearce, J. A. \& Potts, P. J., 1980. Rare earth element mobility during granite alteration; evidence from southwest England. Earth Planet. Sci. Lett. 49, $149-155$.

Alviola, R., 1977. Kajaanin alueen graniittipegmatiitit. Únpubl. Ph.Lic. Thesis, Dept. Geol., Univ. Helsinki, 82 p.

Anderson, J. L., 1983. Proterozoic anorogenic granite plutonism of North America. Geol. Soc. Am., Mem. 161, $133-154$. ochemical and isotopic data in particular, the granitoids can be divided into definite major groups with different geological, petrological, geochemical, metallogenic and geochronological features. These differences must be consequences of the characteristic petrogenesis of the granitoids (Table 4).

The concept of the granite types seems to be valid in the Proterozoic as well, at least in the Baltic Shield. Distinct analogies can be found for the I-, S- and A-type granites, which comprise the most important Proterozoic granitoids of Finland.

The granitoids are indicative of different stages of crustal evolution. They were formed during the building and metamorphism of the crust and during post-orogenic faulting. Present knowledge of the areal distribution of the granite types and their various subgroups is, however, insufficient to be utilized in paleogeographical interpretations of crustal evolution.

Acknowledgements. The authors are grateful to A. Vorma, K. Korsman and K. Front for critically reading the manuscript. The English was revised by G. Häkli and P. Sjöblom.
Aro, K., 1983. Hämeenkyrön batoliitin sekä Ylöjärven ja Oriveden metavulkaniittien $\mathrm{Rb}$-Sr-menetelmään perustuva kokokivi-iänmääritys. Unpubl. M.Sc. Thesis, Dept. Geol., Univ. Helsinki, 73 p.

Arth, J. G.; Barker, F.: Peterman, Z. E. \& Friedman, I., 1978. Geochemistry of the gabbro-diorite-tonalitetrondhjemite suite of southwest Finland and its implications for the origin of tonalitic and trondhjemitic magmas. J. Petrol. 19, 289-316.

Aurola, E., 1963. On the pegmatites in the Torro area, southwestern Finland. Bull. Comm. Géol. Finl. 206, 32 p.

Bachinski, S. W. \& Scott, R. B., 1979. Rare-earth and other trace element contents and the origin of minettes (micalamprophyres). Geochim. Cosmochim. Acta 43, 93-100. Barker, F.; Arth, J. G \& Hudson, T., 1981. Tonalites in 
crustal evolution. Phil. Trans. K. Soc. Lond. A 301, 293-303.

-; Arth, J. G.; Peterman, Z. E. \& Friedman, I., 1976. The 1.7- to 1.8-b.y.-old trondhjemites of southwestern Colorado and northern New Mexico: geochemistry and depth of genesis. Geol. Soc. Am., Bull. 87, 189-198.

Beckinsale, R. D., 1979. Granite magmatism in the tin-belt of southeast Asia. In Atherton, M. P. and Tarney, J. (Editors) Origin of Granite Batholiths: Geochemical Evidence: Shiva Publ. Ltd., Orpington, 34-44.

Bergman, L., 1981. Berggrunden inom Signilsskär, Mariehamn och Geta kartblad - Signilskärin, Maarianhaminan ja Getan kartta-alueiden kallioperä. Summary: PreQuaternary rocks of the Signilskär, Mariehamn and Geta mapsheet areas. Suomen geologinen kartta 1:100 000, Kallioperäkarttojen selitykset, $0034+0043$ Signilskär, 1012 Maarianhamina ja 1021 Geta. 72 p.

Bowes, D. R. \& McArthur, A. C., 1976. Nature and genesis of the Appinite suite. Krystalinikum 12, 31-46.

-; Halden, N. M.; Koistinen, T. J. \& Park, A. F., 1984. Structural features of basement and cover rocks in the eastern Svecokarelides, Finland. In Kröner, A. and Greiling, R. (Editors) Precambrian Tectonics Illustrated. E. Schweizerbart'sche Verlagsbuchhandlung (Nägele u. Obermiller), Germany, Stuttgart, 147-171.

Bridgwater, D.; Sutton, J. \& Watterson, J., 1974. Crustal downfolding associated with igneous activity. Tectonophysics $21,57-77$.

Brown, G. C., 1982. Calc-alkaline intrusive rocks: their diversity, evolution, and relation to volcanic arcs. In Thorpe, R. S. (Editor) Andesites, Orogenic Andesites and Related Rocks. John Wiley \& Sons, Chichester, 437-461.

Bukharev, V. P.; Stekolinikova, A. V.\& Polyanskiy, V. D., 1973. Tectonics and deep structure of anorthosite massifs in the northwest Ukrainian Shield. Geotectonics 4, 207-210.

Burnham, C. W. \& Ohmoto, H., 1980. Late-stage processes of felsic magmatism. In Ishihara, S. and Takenouchi, S. (Editors) Granitic Magmatism and Related Mineralization. Min. Geol., Spec. Issue 8, 1-11.

Chappell, B. W. \& White, A. J. R., 1974. Two contrasting granite types. Pac. Geol. 8, 173-174.

Chorlton, L. B. \& Martin, R. F., 1978. The effect of boron on the granite solidus. Can. Mineral. 16, 239-244.

Clarke, D. B., 1981. The mineralogy of peraluminous granites: a review. Can. Mineral. 19, 3-17.

Clemens, J. D. \& Wall, V. J., 1981. Origin and crystallization of some peraluminous (S-type) granitic magmas. Can. Mineral. 19, 111-131.

Collins, W. J.; Beams, S. D.; White, A. J. R. \& Chappell, B. W. 1982. Nature and origin of A-type granites with particular reference to southeastern Australia. Contrib. Mineral. Petrol. 80, 189-200.

Condie, K. C.\& McCrink, T. P., 1982. Geochemistry of Pro- terozoic volcanic and granitic rocks from the Gold Hill - Wheeler Peak area, northern New Mexico. Precambrian Res. 19, 141-166.

Cullers, R. L. \& Graf, J. L., 1984. Rare earth elements in igneous rocks of the continental crust: intermediate and silicic rocks - ore petrogenesis. In Henderson, P. (Editor) Rare Earth Element Geochemistry. Elsevier, Amsterdam, 275-316.

DePaolo, D. J., 1981. Neodymium isotopes in the Colorado Front Range and crust-mantle evolution in the Proterozoic. Nature 21, 193-196.

Dubrovsky, M. I., 1965. Zhilnye greyzeny i kvartsevye zhily $s$ greyzenovymi otorochkami gory youvv-oayv (in Russian). In Materialy po mineralogii Kolskogo poluostrova. Nauka, Moscow, 81-96.

Ehlers, C. \& Bergman, L., 1984. Structure and mechanism of intrusion of two postorogenic granite massifs, southwestern Finland. In Kröner, A. and Greiling, R. (Editors) Precambrian Tectonics Illustrated. E. Schweizerbart'sche Verlagsbuchhandlung (Nägele u. Obermiller), Germany, Stuttgart, 173-190.

Emslie, R. F., 1978. Anorthosite massifs, rapakivi granites, and late Proterozoic rifting of North America. Precambrian Res. 7, 61-98.

-, 1980. Geology and petrology of the Harp Lake complex, central Labrador: an example of Elsonian magmatism. Geol. Surv. Can., Bull. 293, 136 p.

Eskola, P. E., 1932. On the origin of granitic magmas. Mineral. Petrol. Mitt. 42, 455-481.

-, 1960. Granitentstehung bei Orogenese und Epirogenese. Geol. Rundsch. 50, 105-113.

Fourcade, S. \& Allegre, C. J., 1981. Trace elements behavior in granite genesis: a case study. The calc-alkaline plutonic association from the Querigut complex (Pyrénées, France). Contrib. Mineral. Petrol. 76, 177-195.

Fowler, A. D. \& Doig, R., 1983. The significance of europium anomalies in the REE spectra of granites and pegmatites, Mont Laurier, Quebec. Geochim. Cosmochim. Acta 47, 1131-1137.

Frey, F. A.; Chappell, B. W. \& Roy, S. D., 1978. Fractionation of rare-earth elements in the Tuolumne Intrusive Series, Sierra Nevada batholith, California. Geology 6, 239-242.

Front, K., 1985. Etelä-Suomen svekokarjalaisten synorogeenisten granitoidi-intruusioiden luonteenomaisia piirteitä ja petrogenesis. Unpubl. Ph.Lic. Thesis, Dept. Geol., Univ. Helsinki, $100 \mathrm{p}$.

Gaál, G., 1982 a. Proterozoic tectonic evolution and late Svecokarelian plate deformation of the Central Baltic Shield. Geol. Rundsch. 71, 158-170.

-, 1982 b. Nickel metallogeny related to tectonics in the central Baltic Shield. Rev. Bras. Geosciências 12, 437-444.

- \& Isohanni, M., 1979. Characteristics of igneous intrusions and various wall rocks in some Precambrian por- 
phyry copper-molybdenum deposits in Pohjanmaa, Finland. Econ. Geol. 74, 1198-1210.

-; Front, K. \& Aro, K., 1981. Geochemical exploration of a Precambrian batholith, source of a $\mathrm{Cu}-\mathrm{W}$ mineralization of the tourmaline breccia type in southern Finland. J. Geochem. Explor. 15, 683-698.

-; Mikkola, A. \& Söderholm, B., 1978. Evolution of the Archean crust in Finland. Precambrian Res. 6, 199-215.

Gaudette, H. E.; Mendoza, V.; Hurley, P. M. \& Fairbairn, H. W., 1978. Geology and age of the Parguaza rapakivi granite, Venezuela. Geol. Soc. Am., Bull. 89, 1335-1340.

Green, $T . H ., 1980$. Island arc and continent-building magmatism - a review of petrogenetic models based on experimental petrology and geochemistry. Tectonophysics 63, 367-385.

Gulson, B. L. \& Krogh, T. E., 1975. Evidence of multiple intrusion, possible resetting of $\mathrm{U}-\mathrm{Pb}$ ages, and new crystallization of zircons in the post-tectonic intrusions (' $\mathrm{Ra}$ pakivi granites') and gneisses from South Greenland. Geochim. Cosmochim. Acta 39, 65-82.

Haapala, I., 1966. On the granitic pegmatites of the Peräseinäjoki-Alavus area, South Pohjanmaa, Finland. Bull. Comm. Géol. Finl. 224, 98 p.

,- 1974 . Some petrological and geochemical characteristics of rapakivi granite varieties associated with greisen-type $\mathrm{Sn}, \mathrm{Be}$ and $\mathrm{W}$ mineralization in the Eurajoki and Kymi areas, Southern Finland. In Stemprok, M. (Editor) Metallization Associated with Acid Magmatism. Geol. Surv. Prague, 159-169.

—, 1977 a. Petrography and geochemistry of the Eurajoki stock; a rapakivi-granite complex with greisen-type mineralization in southwestern Finland. Geol. Surv. Finl., Bull. 286, 128 p.

-, $1977 \mathrm{~b}$. The controls of tin and related mineralizations in the rapakivi areas in south-eastern Fennoscandia. Geol. Fören. Stockh., Förh. 99, 130-142.

—, 1983. Metallogeniya dokembriyskikh granitoidov Finlandii (in Russian). English abstract: Metallogeny of the Precambrian granitoids of Finland. In Beus, A. A. (Editor) Metallogeniya dokembriyskikh granitoidov. Nauka, Moscow, 25-71.

- \& Kinnunen, K., 1979. Fluid inclusions in cassiterite and beryl in greisen veins in the Eurajoki stock, southwestern Finland. Econ. Geol. 74, 1231-1238.

— \& Ojanperä, P., 1972. Genthelvite-bearing greisens in southern Finland. Geol. Surv. Finl. Bull. 259, 22 p.

Hanson, G. N., 1980. Rare earth elements in petrogenetic studies of igneous systems. Annu. Rev. Earth Planet. Sci. 8, 371-406.

Härme, M., 1965. On the potassium migmatites of southern Finland. Bull. Comm. Géol. Finl. 219, 43 p.

- \& Seitsaari, J., 1950. On the structure of tilted dome near Tampere in southern Finland. Bull. Comm. Géol. Finl. 150, 19-22.
Harris, P. G.; Kennedy, W. Q. \& Scarfe, C. M., 1970. Volcanism versus plutonism - the effect of chemical composition. In Newall, G. and Rast, N. (Editors) Mechanism of Igneous Intrusion. Gallery Press, Liverpool, 187-200.

Hietanen, A., 1975. Generation of potassium-poor magmas in the northern Sierra Nevada and the Svecofennian of Finland. J. Res. U. S. Geol. Surv. 3, 631-645.

Himmi, R.; Huhma, M. \& Häkli, T. A., 1979. Mineralogy and metal distribution in the copper-tungsten deposit at Ylöjärvi, southwest Finland. Econ. Geol. 74, 1183-1197.

Hopgood, A. M.; Bowes, D. R.; Kouvo, O. \& Halliday, A. $N$., 1983. U-Pb and $\mathrm{Rb}-\mathrm{Sr}$ isotopic study of polyphase deformed migmatites in the Svecokarelides, southern Finland. In Atherton, M. P. and Gribble, C. D. (Editors) Migmatites, Melting and Metamorphism. Shiva Publishing Ltd., Nantwich, 80-92.

Huhma, A, 1981. Youngest Precambrian dyke rocks in North Karelia, eastern Finland. Bull. Geol. Soc. Finl. 53, 67-82.

Hyndman, D. W., 1981. Controls of source and depth of emplacement of granitic magma. Geology 9, 244-249.

Inkinen, E., 1984. Malmimineraalit ja sivukivien muuttuminen Etelä- ja Länsi-Suomen svekokarjalaisissa, porfyyrityyppisissä Mo- ja Cu-esiintymissä. Unpubl. M.Sc. thesis, Dept. Geol., Univ. Helsinki, 97 p.

Ishihara, S., 1977. The magnetite-series and ilmenite-series granitic rocks. Min. Geol. 27, 293-305.

—, 1978. Metallogenesis in the Japanese island arc system. J. Geol. Soc. Lond. 135, 389-406.

-, 1981. The granitoid series and mineralization. In Skinner, B. J. (Editor) Econ. Geol., 75th Anniv. Vol., 458484.

Jahn, B.; Sun, S. S. \& Nesbitt, R. W., 1979. REE distribution and petrogenesis of the Spanish Peaks igneous complex, Colorado. Contrib. Mineral. Petrol 70, 281-298.

Kaitaro, S., 1953. Geologic structure of the late Pre-Cambrian intrusives in the Åva area, Åland Islands. Bull. Comm. Géol. Finl. 162, 71 p.

Kallio, P. \& Alviola, R., 1974. Triphyllites and lithiophilites from the granite pegmatites of the communes of Kitee and Tohmajärvi, E Finland. Fortschr. Miner. 52, 279283.

Kerrich, R. \& Fryer, B. J., 1979. Archean precious metal hydrothermal systems, Dome mine, Abitibi Greenstone Belt, II. REE and oxygen isotope relations. Can. J. Earth Sci. 16, 440-458.

Korsman, K., 1977. Progressive metamorphism of the metapelites in the Rantasalmi-Sulkava area, southeastern Finland. Geol. Surv. Finl., Bull. 290, 82 p.

— \& Lehijärvi, M., 1973. Sulkavan kartta-alueen kallioperä. Summary: Precambrian rocks of the Sulkava mapsheet area. Suomen geologinen kartta, 1 : 100 000, Kallioperäkartan selitykset, 3144 Sulkava. 24 p.

-; Hölttä, P.; Hautala, T. \& Wasenius, P., 1984. Metamorphism as an indicator of evolution and structure of 
the crust in Eastern Finland. Geol. Surv. Finl., Bull. 328, $40 \mathrm{p}$.

Kouvo, O.; Huhma, H. \& Sakko, M., 1983. Isotope evidence for old crustal involvement in the genesis of two granites from northern Finland. Abstr. 2nd. E.U.G. Meeting, Strassbourg. Terra Cognita 3(2-3), 135.

Kovalenko, V. I., 1973. Distribution of fluorine in a topazbearing quartz keratofyre (ongonite) and solubility of fluorine in granitic melts. Geochem. Int. 10, 41-49.

Lahti, S. I., 1981. On the granitic pegmatites of the Eräjärvi area in Orivesi, southern Finland. Geol. Surv. Finl., Bull. 314, $82 \mathrm{p}$.

Laitakari, I., 1969. On the set of olivine diabase dikes in Häme, Finland. Bull. Comm. Géol. Finl. 241, 65 p.

—, 1985. Hämeen ja Kaakkois-Suomen subjotuniset diabaasit. In Aro, K. and Laitakari, I. (Editors), Suomen diabaasit ja muut mafiset juonikivilajit. Summary: Diabases and other mafic dyke rocks in Finland. Geol. Surv. Finl., Rep. Invest. (in press).

Lauerma, R., 1982. On the ages of some granitoid and schist complexes in northern Finland. Bull. Geol. Soc. Finl. 54, 85-100.

Laukkanen, J., 1985. Väli-Suomen lamprofyyrijuonet. In Aro, K. and Laitakari, I. (Editors), Suomen diabaasit ja muut mafiset juonikivilajit. Summary: Diabases and other mafic dyke rocks in Finland. Geol. Surv. Finl., Rep. Invest. (in press).

Lauren, L., 1970. An interpretation of the negative gravity anomalies associated with the rapakivi granites and the Jotnian sandstone in southern Finland. Geol. Fören. Stockh., Förh. 92, 21-94.

Lawrence, G., 1975. The use of rubidium/strontium ratios as a guide to mineralization in the Galway granite, Ireland. In Elliot, I. L. and Fletcher, W. K. (Editors) Geochemical Exoploration 1974. Elsevier, Amsterdam, $353-370$.

Lindqvist, K. \& Laitakari, I., 1980. Glass and amygdules in Precambrian diabases from Orivesi, southern Finland. Bull. Geol. Soc. Finl. 52, 221-229.

Lof, P. \& Hazebroek, H. P., 1976. Geology and petrology of some selected pegmatites of the area between Lemnästräsket and Mattkärr. Manuscript. Dept. Ore Geol. Petrol. Mineral., Free Univ. Amst.

Loiselle, M. C. \& Wones, D. R., 1979. Characteristics and origin of anoreogenic granites. Geol. Soc. Am., Abstr. Programs 11, 468.

Lundberg, B., 1980. Aspects of the geology of the Skellefte field, northern Sweden. Geol. Fören. Stockh., Förh. 102, $156-166$.

Mäkelä, K., 1980. Geochemistry and origin of Haveri and Kiipu, Proterozoic strata-bound volcanogenic gold-copper and zinc mineralizations from southwestern Finland. Geol. Surv. Finl., Bull. 310, 79 p.

Mäkinen, E., 1913. Die Granitpegmatite von Tammela in Fin- land und ihre Minerale. Bull. Comm. Géol. Finl. 35, $101 \mathrm{p}$.

Manning, D. A. C., 1982. An experimental study of the effects of fluorine on the crystallization of granitic rocks. In Ewans, A. M. (Editor) Metallization Associated with Acid Magmatism, Vol. 6. John Wiley \& Sons, Chichester, $191-203$.

Marttila, E., 1976. Evolution of the Precambrian volcanic complex in the Kiuruvesi area, Finland. Geol. Surv. Finl., Bull. 283, 109 p.

McCulloch, M. T\& Chappell, B. W., 1982. Nd isotopic characteristics of S- and I-type granites. Earth Planet. Sci. Lett. 58, 51-64.

Meriläinen, K., 1976. The granulite complex and adjacent rocks in Lapland, northern Finland. Geol. Surv. Finl., Bull. 281, 129 p.

Mikkola, E., 1928. Über den Nattanengranit im Finnischen Lappland. Fennia 50 (12), 1-22.

—, 1941. Kivilajikartan selitys, Lehdet — Sheets B7-C7-D7, Muonio-Sodankylä-Tuntsajoki. English summary: Explanation to the Map of Rocks. Suomen Geologinen Yleiskartta $1: 400000,286$ p.

Miller, C. F. \& Mittlefehldt, D. W., 1982. Depletion of light rare-earth elements in felsic magmas. Geology 10, 129133.

Mineyev, D. A., 1963. Geochemical differentiation of the rare earths. Geochemistry 12, 1129-1149.

Mitchell, R. \& Brunfelt, A. O., 1975. Rare-earth element geochemistry of kimberlite. Phys. Chem. Earth 9, 671686.

Nagasawa, H., 1970. Rare earth concentration in zircon and apatite and their host dacites and granites. Earth Planet. Sci. Lett. 9, 359-364.

Nance, W. B. \& Taylor, S. R., 1976. Rare earth element patterns and crustal evolution-I. Australian post-Archean sedimentary rocks. Geochim. Cosmochim. Acta 40, $1539-1551$.

Nelson, B. K.\& DePaolo, D. J., 1982. Crust formation age of the North American Midcontinent. Geol. Soc. Am., Abstr. Programs 14 (7), 575.

Neuvonen, K. J.: Korsman, K.; Kouvo, O. \& Paavola, J., 1981. Paleomagnetism and age relations of the rocks in the Main Sulphide Ore Belt in central Finland. Bull. Geol. Soc. Finl. 53, 109-133.

Nironen, M., 1985. Eräiden svekokarjalaisten granitoidien intruusiomekanismit ja tektoninen asema sekä niihin liittyvien porfyyrityyppisten Mo- ja Cu-esiintymien rakenne. Unpubl. Ph.Lic. Thesis, Dept. Geol., Univ. Helsinki, $97 \mathrm{p}$.

- \& Csongrádi, J., 1984. Characteristics of the Proterozoic porphyry-type $\mathrm{Cu}$ occurrence at Tienpää, Halsua, western Finland. Bull. Geol. Soc. Finl. 56, 89-97.

Nurmi, P. A., 1983. Trace element variations in the midProterozoic Rautio batholith, Finland: petrogenetic im- 
plications. In Augustithis, S. S. (Editor) The Significance of Trace Elements in Solving Petrogenetic Problems \& Controversies. Theophrastus Publ. S. A., Athens, 353376.

-, 1984. Applications of lithogeochemistry in the search for Proterozoic porphyry-type molybdenum, copper and gold deposits, southern Finland. Geol. Surv. Finl., Bull. 329, $40 \mathrm{p}$.

-, 1985. Lithogeochemistry in exploration for Proterozoic porphyry-type molybdenum and copper deposits, southern Finland. J. Geochem. Explor. 23, 163-191.

— \& Isohanni, M., 1984. Rock, till, and stream-sediment geochemistry in the search for porphyry-type $\mathrm{Mo}-\mathrm{Cu}-\mathrm{Au}$ deposits in the Proterozoic Rautio batholith, western Finland. J. Geochem. Explor. 21, 209-228.

-; Front, K.; Lampi, E. \& Nironen, M., 1984. Etelä-Suomen svekokarjalaiset porfyyrityyppiset molybdeeni- ja kupariesiintymät, niiden granitoidi-isäntäkivet ja litogeokemiallinen etsintä. Summary: Svecokarelian porphyry-type molybdenum and copper occurrences in southern Finland: their granitoid host rocks and lithogeochemical exploration. Geol. Surv. Finl., Rep. Invest., 67, 88 p.

Nykänen, O., 1968. Kallioperäkartan selitys, Tohmajärvi 4232-4234. English summary: Explanation to the map of rocks. Suomen geologinen kartta, 1: 100000 , 4232-4234 Tohmajärvi. 68 p.

Nyström, J. O., 1982. Post-Svecokarelian Andinotype evolution in central Sweden. Geol. Rundsch. 71, 141-157.

Othman, D. B.; Fourcade, S. \& Allégre, C. J., 1984. Recycling processes in granite-granodiorite complex genesis: the Querigut case studied by Nd-Sr isotope systematics. Earth Planet. Sci. Lett. 69, 290-300.

Parras, K., 1958. On the charnockites in the light of a highly metamorphic rock complex in southwestern Finland. Bull. Comm. Géol. Finl. 181, 137 p.

Patchett, P. J.\& Bridgwater, D., 1984. Origin of continental crust of 1.9.-1.7. Ga age defined by $\mathrm{Nd}$ isotopes in the Ketilidian terrain of South Greenland. Contrib. Mineral. Petrol, 87, 311-318.

-; Gorbatschev, R.; Kouvo, O. \& Todt, W., 1984. Origin of continental crust of $1.9-1.7 \mathrm{Ga}$ age: Nd isotopes in the Svecokarelian terrain of Sweden and Finland. Geol. Soc. Am., Abstr. Programs 16, 619.

-; Kouvo, O.; Hedge, C. E. \& Tatsumoto, M., 1981. Evolution of continental crust and mantle heterogeneity: Evidence from Hf isotopes. Contrib. Mineral. Petrol. 78, 279-297.

Paul, D. K. \& Potts, P. J., 1981. Rare earth abundances and origin of some Indian lamprophyres. Geol. Mag. 118, 393-399.

Pehrman, G., 1945. Die Granitpegmatite von Kimito (SWFinland) und ihre Minerale. Medd. Åbo Akad., Geol. Mineral. Inst. 26, 1-84.

Peuraniemi, V.; Mattila, E.; Nuutilainen, J. \& Autio, H.,
1983. Till and bedrock geochemistry in tin exploration. 10th Int. Geochem. Explor. Symp. - 3rd Symp. Methods Geochem. Prospect., Abstr. Geol. Surv. Finl., 60-61.

Pitcher, W. S. 1983. Granite type and tectonic environment. In Hsii, K. J. (Editor) Mountain Building Processes. Academic Press, London, 19-40.

Pitkänen, P., 1985. Anttolan Luonterin postorogeenisen intruusion petrologia ja geokemia. Unpubl. M.Sc. Thesis, Dept. Geol., Univ. Helsinki, 81 p.

Plimer, I. R., 1980. Exhalative Sn and W deposits associated with mafic volcanism as precursors to $\mathrm{Sn}$ and $\mathrm{W}$ deposits associated with granites. Miner. Deposita 15, 275-289.

—, 1983. The Geology of Tin and Tungsten Deposits. Course Handbook, Inst. Miner. Petrol, Min. Univ., Leoben, Austria, 212 p.

Pushkarev, Yu. D.; Vetrin, V. R.; Vinogradov, A. N.; Vinogradova, G. V.; Kvarchenko, E. V.; Shestakov, G. I.; Belkov, Ye. I.; Ryungenen, G. I.; Surovtseva, L. N.; Obukhova, L. A. \& Ulyanenko, N. A. 1975. Vozrastnoye polozheniye litsko-aragubskogo i umbinskogo kompleksov porfirovidnykh granitoidov po dannym U-Th- $\mathrm{Pb}$, Rb-Sr, K-Ar metodov (in Russian). In Batiyeva, I. D. (Editor) Intruzivnye charnokity i porfirovidnye granity Kolskogo poluostrova. Nauka, Moscow, 340-353.

Rickard, D. T., 1978. The Svecokarelian anomalous ore lead line. Geol. Fören. Stockh., Förh. 100, 19-30.

- \& Zweifel, H., 1975. Genesis of Precambrian sulfide ores, Skellefte District, Sweden. Econ. Geol. 70, 255-274.

Rock, N. M. S., 1977. The nature and origin of lamprophyres: some definitions, distinctions and derivations. Earth Sci. Rev. 13, 123-169.

Rub, M. G.; Pavlov, V. A.; Gladkov, N. G. \& Jas̄ukin, O. J. M., 1982. Olovonosnye i voliframonosnye granitoidy nekotoryh regionov SSSR (in Russian). Nauka, Moscow.

Ruitenberg, A. A. \& Fyffe, L. R., 1982. Mineral deposits associated with granitoid intrusions and related subvolcanic stocks in New Brunswick and their relationship to Appalachian tectonic evolution. Can. Inst. Min. Metall., Bull. 75 (842), 83-97.

Sahama, Th. G., 1945. On the geochemistry of the east Fennoscandian rapakivi granites. Bull. Comm. Géol. Finl. $136,15-67$.

Saksela, M., 1936. Über die geologische Kartierung und die Einteilung der Granite im finnischen Grundgebirge. Bull. Comm. Géol. Finl. 115, 275-292.

Saunders, A. D.; Tarney, J. \& Weaver, S. D., 1980. Transverse geochemical variations across the Antarctic Peninsula: implications for the genesis of calc-alkaline magmas. Earth Planet. Sci. Lett. 46, 344-360.

Savolahti, A., 1956. The Ahvenisto massif in Finland. Bull. Comm. Géol. Finl. 174, 96 p.

Sederholm, J. J., 1932. On the geology of Fennoscandia with special reference to the pre-Cambrian. Bull. Comm. Géol. Finl. 98, 30 p. 
Sillitoe, R. H., 1979. Some thoughts on gold-rich porphyry copper deposits. Miner. Deposita 14, 161-174.

— \& Sawkins, F. J., 1971. Geologic, mineralogic and fluid inclusion studies relating to the origin of copper-bearing tourmaline breccia pipes, Chile. Econ. Geol. 66, 10281041.

Simonen, A., 1960. Plutonic rocks of the Svecofennides in Finland. Bull. Comm. Géol. Finl. 189, 101 p.

—, 1980. The Precambrian in Finland. Geol. Surv. Finl., Bull. 304, 58 p.

—, 1982. Mäntyharjun ja Mikkelin kartta-alueiden kallioperä. Summary: Pre-Quaternary rocks of the Mäntyharju and Mikkeli map-sheet areas. Suomen geologinen kartta, $1: 100000$. Kallioperäkarttojen selitykset, 3123 Mäntyharju ja 3142 Mikkeli. 36 p.

- \& Vorma, A., 1969. Amphibole and biotite from rapakivi. Bull. Comm. Géol. Finl. 238, 28 p.

Stewart, D. B., 1978. Petrogenesis of lithium-rich pegmatites. Am. Mineral. 63, 970-980.

Streckeisen, A. L., 1974. Classification and nomenclature of igneous rocks. Geol. Rundsch. 63, 773-786.

Takahashi, M.; Aramaki, S. \& Ishihara, S., 1980. Magnetiteseries/ilmenite series vs. I-type/S-type granitoids. In Ishihara, S. and Takenouchi, S. (Editors) Granitic Magmatism and Related Mineralization. Min. Geol., Spec. Issue $8,13-28$.

Taylor, S. R., 1965. Application of trace element data to problems in petrology. Phys. Chem. Earth 6, 133-213.

Thompson, R. N.; Morrison, M. A.; Hendry, G. L. \& Par$r y, S . J ., 1984$. An assesment of the relative roles of crust and mantle in magma genesis: an elemental approach. Phil. Trans. R. Soc. Lond. A310, 549-590.

Törnroos, R., 1984. Petrography, mineral chemistry and petrochemistry of granite porphyry dykes from Sibbo, southern Finland. Geol. Surv. Finl., Bull. 326, 43 p.

Vaasjoki, M., 1977. Rapakivi granites and other postorogenic rocks in Finland: their age and the lead isotopic composition of certain associated galena mineralizations. Geol. Surv. Finl., Bull. 294, 64 p.

,- 1981 . The lead isotopic composition of some Finnish galenas. Geol. Surv. Finl., Bull. 316, 30 p.

Vetrin, V. R.; Vinogradov, A. N. \& Vinogradova, G. V., 1975. Petrologiya i fatsialno-formatsionnyi analiz litskoaragubskogo diorit-granitnogo kompleksa (in Russian). In Batiyeva, I. D. (Editor) Intruzivnye charnokity i porfirovidnye granity Kolskogo poluostrova. Nauka, Moscow, 149-317.

Volborth, v., A., 1954. Phosphatminerale aus dem Lithiumpegmatite von Viitaniemi, Eräjärvi, Zentral-Finnland. Ann. Acad. Sci. Fenn. A 29, 90 p.

Vorma, A., 1971. Alkali feldspar of the Wiborg rapakivi massif in southeastern Finland. Bull. Comm. Géol. Finl. 246, $72 \mathrm{p}$.
,- 1972 . On the contact aureole of the Wiborg rapakivi granite massif in southeastern Finland. Geol. Surv. Finl., Bull. 255, 28 p.

,- 1975 . On two roof pendants in the Wiborg rapakivi massif, southeastern Finland. Geol. Surv. Finl., Bull. 272, $86 \mathrm{p}$.

-, 1976. On the petrochemistry of rapakivi granites with special reference to the Laitila massif, southwestern Finland. Geol. Surv. Finl., Bull. 285, 98 p.

—; Ojanperä, P.; Hoffrén, V.; Siivola, J. \& Löfgren, A., 1966. On the rare earth minerals from the Pyörönmaa pegmatite in Kangasala, SW-Finland. Bull. Comm. Géol. Finl. 222, 241-274.

Wahl, W., 1925. Die Geistene des Wiborger Rapakivigebites. Fennia 45 (20), 1-127.

-, 1936. The granites of the Finnish part of the Svecofennian Archaean mountain chain. Bull. Comm. Géol. Finl. 115, 489-505.

-, 1947. A composite lava flow from Lounatkorkia, Hogland. Bull. Comm. Géol. Finl. 140, 287-302.

,- 1963 . The hypersthene granites and unakites of Central Finland. Bull. Comm. Géol. Finl. 212, 83-100.

Watson, E. B., 1979. Zircon saturation in felsic liquids: experimental results and applications to trace element geochemistry. Contrib. Mineral. Petrol 70, 407-419.

Welin, E. \& Lundqvist, T., 1984. Isotopic investigations of the Nordingrå rapakivi massif, north-central Sweden. Geol. Fören. Stockh., Förh. 106, 41-49.

-; Vaasjoki, M. \& Suominen, V., 1983. Age differences between $\mathrm{Rb}-\mathrm{Sr}$ whole rock and U-Pb zircon ages of synand postorogenic Svecokarelian granitoids in Sottunga, SW Finland. Lithos 16, 297-305.

White, A. J. R., 1979. Sources of granite magmas. Geol. Soc. Am., Abstr. Programs 11, 539.

- \& Chappell, B. W., 1977. Ultrametamorphism and granitoid genesis. Tectonophysics 43, 7--22.

- \& Chappell, B. W., 1983. Granitoid types and their distribution in the Lachlan Fold Belt, southeastern Australia. Geol. Soc. Am., Mem. 159, 21-34.

Wilson, M. R., 1980. Granite types in Sweden. Geol. Fören. Stockh., Förh. 102, 167-176.

- , 1982. Magma types and the tectonic evolution of the Swedish Proterozoic. Geol. Rundsch. 71, 102-129.

Wyllie, P. J.; Huang, W.-L.; Stern, C. R. \& Maaløe, S., 1976. Granitic magmas: possible and impossible sources, water contents, and crystallization sequences. Can. J. Earth Sci. 13, 1007-1019.

Yletyinen, V., 1967. Ylitornion Kivilompolon molybdeenihohde-esiintymistä. Geol. Surv. Finl., Geotek. julk. 73, $21 \mathrm{p}$.

Zwart, H. J., 1967. The duality of orogenic belts. Geol. Mijnbouw 46, 283-309. 